\title{
A COMPARATIVE STUDY BETWEEN GARLIC EXTRACT AND HYDROGEN CYANAMIDE ON FLOWERING, FRUIT SET AND PRODUCTIVITY OF GRAPES
}

\author{
Eman I. El-Amary and Sheren A. Abd El-Hamied* \\ Department of Plant Production, Desert Research Center, El-Matareya, \\ Cairo, Egypt \\ *E-mail: sherenadel3m@yahoo.com
}

$\mathrm{T}$ his experiment was carried out during 2016 and 2017 seasons on Flame Seedless grapevines grown at ElKhatatba district, in Menofia Governorate, Egypt. Climate is one of the important factors that control grape production, in warm-winter regions, where the need of intervention of chemical means to break bud rest becomes a dominant factor for maintaining economic production of table grapes. However, the problem is more acute when farmers want to grow on organic table grapes in the absence of environmentally friendly natural bud break promoters. This study aimed to evaluate the effect of a garlic extract in comparison to the conventional use of hydrogen cyanamide in promoting bud break and their effects on cluster quality of Flame Seedless grapevines, aiming to invade the markets earlier to maximize the benefits for the producers and to avoid the negative effects of high summer temperature on the vine clusters quality if harvested late. Moreover, this study is a trail to examine to how extent garlic extract (which contains $\mathrm{GA}_{3}$ like substance) can substitute the declination of chilling hours. Five treatments of foliar application [tap water (control); hydrogen cyanamide $\left(\mathrm{H}_{2} \mathrm{CN}_{2}\right) 3$ and $5 \%$, garlic extract (GE) 3 and 5\%] were applied to the vines on three times [the first $\left(D_{1}\right)$, mid $\left(D_{2}\right)$ and the end $\left(D_{3}\right)$ of December]. The obtained results revealed that all treatments were very effective in stimulating vegetative growth, bud burst \%, yield, physical and chemical characteristics of the fruits. Generally, $\mathrm{D}_{2}$ was better than the other two times of spraying in all parameters. Vines that had been sprayed with 5\% GE on $\mathrm{D}_{2}$ were the best for early harvest time as compared with the two other times. In addition, this treatment increased bud burst, leaves number per new shoot, leaf area and chlorophyll content, cluster weight, yield, the average weight and volume of 100 berries, cluster number, cluster length, cluster width, berry length and diameter, total soluble solid, total sugar, while decreased total acidity. In addition, 
vines that had been sprayed with $5 \%$ GE on $\mathrm{D}_{2}$ gave early blooming (decreasing the time from spraying to blooming).

Keywords: grapevine, garlic extract, hydrogen cyanamide, dormancy

Grapes (Vitis vinefera, $\mathrm{L}$.) is considered as one of the most important deciduous fruit crops in the world. In Egypt, grapes rank the second fruit crop after citrus and have a special economic value for local consumption and export, because of its nice taste, high nutritional value and excellent flavor. Seedless grapes are attracting a great interest for their better eating quality and their high economic return.

Climate is one of the factors that control grape production (Fraga et al, 2014). It is affecting the suitability of certain grape varieties to a particular region (Fraga et al., 2015 and Gladstones, 2016). Analyses of historic climatic changes indicate that the land surface temperature increased by about $1.06{ }^{\circ} \mathrm{C}$ over a period of more than 100 years (IPCC, $2014 \mathrm{a}$ and b). To overcome the dormancy and start a new cycle of vegetation, without delay and within uniformity to the shoots, they need to be exposed to a cold period, variable according to each cultivar (Ben Mohamed et al., 2010). Hawerroth et al. (2013) claim that the dormancy is one of the main factors that influence the production of temperate fruit trees in tropical regions. Therefore, the use of chemicals to overcome dormancy is a key factor of higher production in these regions (Botelho and Müller, $2007 \mathrm{a}$ and b). In vines, which are one of the main temperate climate fruit trees in the world, the necessary period of cold climate to the uniformity of budding and overcome dormancy can range from 50 to 400 hours, at the temperature of $7^{\circ} \mathrm{C}$ (Vasconcelos et al., 2007).

Grapevines are suffering from inadequate winter chilling exhibit that delaying and erratic bud break and decrease shoot and cluster counts per vine, in addition to poor uniformity of fruit development (Lavee et al., 1984 and Wicks et al., 1984). Fruit yield and quality are reduced as a result of warm autumns and winters, that causing insufficient chilling for normal bud break (Wicks et al., 1984). To overcome this problem, many investigations have been conducted to interrupt dormancy in grapevines artificially with synthetic chemicals (Lin and Wang, 1985; Nir et al., 1988; Zelleke and Kliewer, 1989 and Dookoozlian and Wiliams, 1995). The use of natural products in horticultural practices is becoming as the main target for many fruit crop producers, where the world market has been growing rapidly in recent years for organic fruit production (Dimitri and Oberholtzer, 2006). Moreover, many investigators used natural extracts to substitute some of chilling requirements aiming to accelerate bud breaking (El-Desouky et al., 1998 and Wanas et al., 1998).

Egyptian J. Desert Res., 68, No. 2, 199-222 (2018) 
Hydrogen cyanamide $\left(\mathrm{H}_{2} \mathrm{CN}_{2}\right)$ (Dormex, BASF) is the most effective synthetic brands used for bud breaking in grapevine orchards (Zelleke and Kliewer, 1989). It is leads to early bud breaking and vigorous vegetative growth. Despite these attributes, $\mathrm{H}_{2} \mathrm{CN}_{2}$ is not accepted by organic protocols for grape production, because $\mathrm{H}_{2} \mathrm{CN}_{2}$ is a product considered as toxic, negatively impacting the health of the producer and the environment. Thus, it is necessary to find an environmentally friendly and suitable for organic table grape production as safer bud break promoters (Arispuro et al., 2008).

Garlic (Allium sativum L.) is native to central Asia, the Mediterranean region as well as Asia, Africa and Europe. It was known to ancient Egyptians, and has been used for both culinary and medicinal purposes since their time (Harris et al., 2001). Jullyanna et al. (2016) stated that natural garlic extract has a principal action in dormancy breaking of grapevine. Thus, this natural product may be a potential substitute for synthetic growth regulators. Garlic extract contains enzymes, B vitamins, proteins, minerals, saponins, flavonoids, sulphur and allyl group $\left(\mathrm{H}_{2} \mathrm{CHCH}_{2}\right)$, mainly diallyl disulfide. Furthermore, a phytoalexin (allixin) has been found (Pandya et al., 2011). Kubota et al. (1999) stated that the active substances in garlic cloves is about $1-3 \%$ of sulfur compounds are responsible for breaking bud dormancy in grapevine and their effects varied among the concentration and the duration of exposure. In addition, El-Desouky et al. (1998) and Wanas et al. (1998) found that the natural extract of garlic cloves, which contains many growth materials and essential requirements for vegetative and reproductive growth and rich in phytohormones and vitamins, improved growth, sex expression, yield and quality of squash plant. Moreover, Botelho and Müller (2007 a and b), who evaluated using garlic extract (GE) on apple trees and table grapes, Abd El-Razek et al. (2011) on Canino' apricot trees grown under warm winter conditions found that those fruit trees greatly responded to spraying garlic extract by improving productivity and fruit quality. In addition, Chowdhury et al. (2007) found that extracts from garlic improved number of fruits, TSS and yield of mango trees. In addition, Abd El-Razek et al. (2013) found that spraying GE combined with $\mathrm{GA}_{3}$ at $100 \mathrm{ppm}$ is recommended to improve productivity and fruit quality of 'Le Conte' pear trees grown under warm winter conditions in Egypt. Mostafa and El-Yazal (2013) reported that GE enhanced date of floral bud break and increased percentage of bud break, fruit set, total number of fruits and fruit yield per tree of "Anna" apple trees. Oliveira et al. (2009) observed that GE initiated the break dormancy of the pear buds, they adding that treatment with 5\% GE presented similar results to those obtained with $0.52 \% \mathrm{H}_{2} \mathrm{CN}_{2}$. Leonel et al. (2015) reported that fig tree cultivars that sprayed with GE at 3\% gave the highest production as compared with $2 \% \mathrm{H}_{2} \mathrm{CN}_{2}$. Similar results were reported in previous studies, which stated that extracts prepared from fresh garlic improved productivity and fruit

Egyptian J. Desert Res., 68, No. 2, 199-222 (2018) 
quality when applied to grapevine, apple and peach (Serag El-Deen, 2002; Botelho et al., 2007 and Ahmed et al., 2009). Kim and Kim (1999) studied the effect of GE on bud break and flowering of "Daebong" grapes. They observed that all treatments hastened bud break and was very effective on hastening flowering than untreated grapevines. Kim and Kim (2000) mentioned that treating Campbell Early grapevine buds with GE and its ethanol and ethyl ether extracts was effective in increasing percentage of bud break. Shaddad (2010) recorded that application of GE (15\%) and onion extract at $5 \%$ significantly enhanced percentage of bud burst and fruiting bud percentage of "Superior" grapevines. Botelho et al. (2010) reported that the GE showed a great potential for bud break in organic production, by improving the sprouting percentage, number of clusters, accelerating the beginning of sprouting and reducing the cycle between pruning and harvest in grape.

The objective of this study was to evaluate the effect of a natural GE in comparison to the conventional use of $\mathrm{H}_{2} \mathrm{CN}_{2}$ in promoting bud break and their effects on cluster quality of Flame Seedless grapevines, under the studying zone conditions. Aiming to substitute the organic treatments instead of chemical treatments, in addition to invade the markets earlier to maximize the benefits for the producers. Moreover, this study is a trail to examine how to extent $\mathrm{GE}$ (which contains $\mathrm{GA}_{3}$ and $\mathrm{GA}_{3}$ like substance) to improve early bud breaking and avoid the negative effects of high summer temperature on the vine clusters quality if harvested late.

\section{MATERIALS AND METHODS}

This study was conducted during the two successive seasons; 2016 and 2017 in private vineyards at El Khatatba, El Menofia Governorate, Egypt. The experiment included 135 vines arranged in factorial design. Five treatments of foliar application [tap water (control); $\mathrm{H}_{2} \mathrm{CN}_{2}$ (3 and 5\%), GE (3 and $5 \%$ ) were applied to the vines on three times [the first $\left(\mathrm{D}_{1}\right)$, mid $\left(\mathrm{D}_{2}\right)$ and the end $\left(D_{3}\right)$ of December]. Each treatment was represented by three replicates (3 vines/replicate). The selected vines were 7-years old, planted in sandy soil (Table 1) at $1.5 \times 3$ meters under drip irrigation system (Table 2). The vines trained according to the double cordon system. Pruning was carried out at the end week of November by leaving 45-55 buds per vine (20 fruiting spurs of 2-3 buds/spur). It is noticeable that most of grape producers at El Khatatba area spray $\mathrm{H}_{2} \mathrm{CN}_{2}$ as a bud rest barker agent on first of January to harvest their fruits generally on first-mind of July.

Egyptian J. Desert Res., 68, No. 2, 199-222 (2018) 
Table (1). Some physical and chemical properties of the soil experimental orchard.

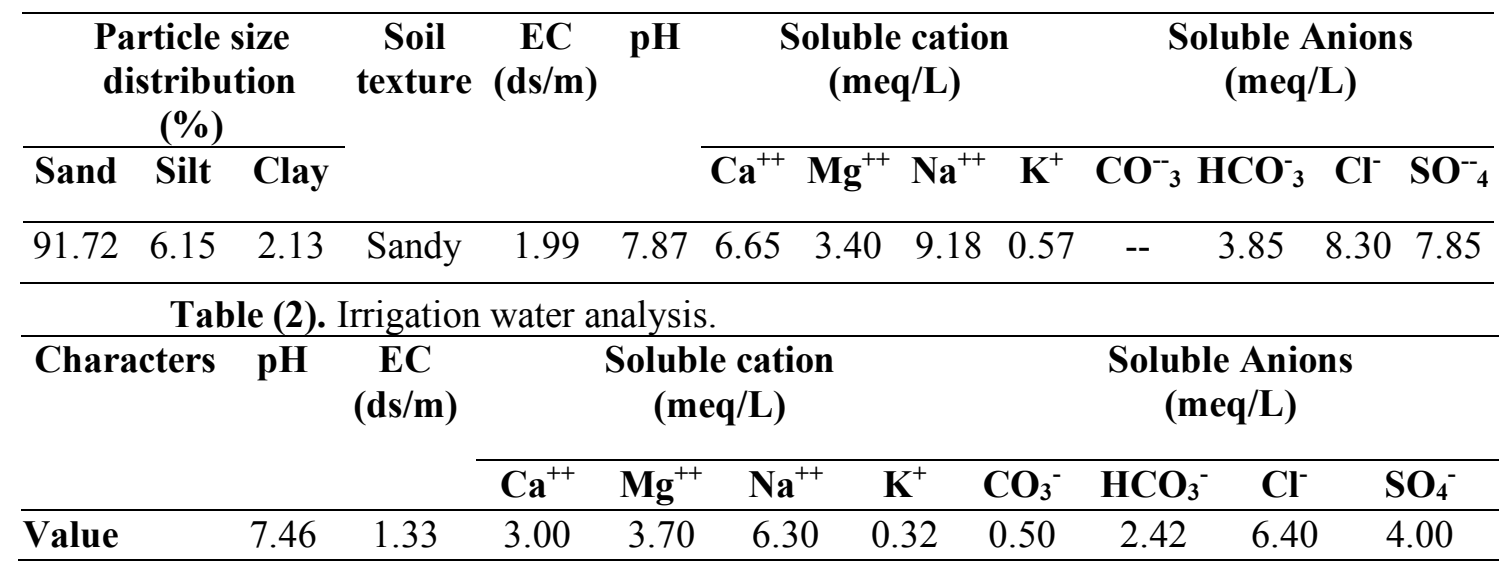

The 3 and 5\% garlic aqueous extract were prepared by blending 30 and $50 \mathrm{~g}$ of fresh mature cloves, respectively, in one liter of distilled water, frozen and thawed two times, and then filtered and diluted by distilled water to one liter (El-Desouky et al., 1998). Some chemical constituents of garlic cloves are shown in table (3).

Table (3). Some chemical constituents of garlic cloves according to Arid Land Agricultural Research Unit.

\begin{tabular}{ll}
\hline Components & Concentration \\
\hline $\mathrm{GA}_{3}$ & $1.633 \mathrm{mg} / 100 \mathrm{~g} \mathrm{F.W}$. \\
$\mathrm{IAA}$ & Trace amount \\
$\mathrm{ABA}$ & Trace amount \\
$\mathrm{Ca}$ & $1.363 \%$ \\
$\mathrm{Mg}$ & $1.230 \%$ \\
$\mathrm{SO}_{4}$ & $0.181 \%$ \\
$\mathrm{Mn}$ & $94.4 \mathrm{ppm}$ \\
$\mathrm{Zn}$ & $66.5 \mathrm{ppm}$ \\
\hline
\end{tabular}

The following parameters were measured:

Buds burst (\%): the percentage of bud burst was calculated according to Bessies (1990).

Time length for blooming: period in days beginning from spraying date to full bloom date.

Number of leaves per shoot: leaves developed on the new shoots were counted at Veraison stage. 
Leaf Area ( $\left.\mathbf{c m}^{2}\right)$ : was determined by using the leaf area meter CL203.

Total chlorophyll content: was measured in fresh leaves in the third leaf from the base at the end of July in field using Minolta meter SPAD-502.

Harvesting date: harvesting of each treatment begins on the date when the clusters reached the fully ripe stage (commercial maturity TSS $\geq 160$ brix). Dates of harvesting were the indicator for measuring the impact of different interactions between date of spray and treatments on detecting the superiority of such treatment in invading market earlier than others, to maximize the economic gain either of the vine orchard or for the producer.

Number of cluster: was recorded/vine.

Cluster weight (g): was determined using 10 clusters per replicate and weighed.

Total yield (kg/vine): The average weight of cluster at harvest date (commercial maturity TSS $\geq 160$ brix) and the yield /vine was expressed as follows: vine yield $(\mathrm{kg})=$ average weight of cluster $(\mathrm{g})$ x number of cluster per vine.

Cluster length and width (cm): at harvesting, two clusters were taken at random from each vine to determine cluster length and width.

Berry dimensions $(\mathbf{c m})$ : berry length and diameter were measured $(\mathrm{cm})$ in 10 berries by using vernal clipper; the average length and diameter of berries were calculated.

Weight and volume 100 berries: weight of 100 berries was determined using digital balance; the volume $\left(\mathrm{cm}^{3}\right)$ of the same berries was determined by the water displacement method.

Soluble solids content (TSS \%): was determined as percentage in juice by means of hand refractometer apparatus according to A.O.A.C. (1985).

Sugar contents in berries Juice (\%): the total sugars were determined according to A.O.A.C. (1985).

Titratable acidity (\%): berries juice titratable acidity was determined according to A.O.A.C. (1990)

Statistical analysis: the obtained data were subjected to analysis of variance according to Clarke and Kempson (1997). Means were differentiated using Range test at the 0.05 level (Duncan, 1955).

\section{RESULTS AND DISCUSSION}

\section{Bud Burst \% and Time Length for Blooming}

Data in table (4) clear that bud burst and time length for blooming were affected significantly by the three dates of spraying in both seasons.

Egyptian J. Desert Res., 68, No. 2, 199-222 (2018) 
Table (4). Effect of spray in three times (D) with hydrogen cyanamide $\left(\mathrm{H}_{2} \mathrm{CN}_{2}\right)$ and garlic extract (GE) on bud burst \% and time length for blooming in Flame Seedless grapevine at 2016 and 2017.

\begin{tabular}{|c|c|c|c|c|}
\hline \multirow{2}{*}{ Treatments } & \multicolumn{2}{|c|}{ Bud burst (\%) } & \multicolumn{2}{|c|}{$\begin{array}{l}\text { Time length for blooming } \\
\text { (No. of days from spraying) }\end{array}$} \\
\hline & $\begin{array}{l}\text { Season } \\
2016\end{array}$ & $\begin{array}{c}\text { Season } \\
2017\end{array}$ & $\begin{array}{c}\text { Season } \\
2016\end{array}$ & $\begin{array}{c}\text { Season } \\
2017\end{array}$ \\
\hline \multicolumn{5}{|c|}{ Effect of spraying dates } \\
\hline $\mathbf{D}_{1}$ & $74.07 \mathrm{c}$ & $74.96 \mathrm{c}$ & $108.48 \mathrm{a}$ & $113.93 \mathrm{a}$ \\
\hline $\mathbf{D}_{2}$ & $80.47 \mathrm{a}$ & $81.22 \mathrm{a}$ & $71.70 \mathrm{c}$ & $77.44 \mathrm{c}$ \\
\hline $\mathbf{D}_{3}$ & $76.86 \mathrm{~b}$ & $77.94 \mathrm{~b}$ & $82.19 b$ & $88.39 \mathrm{~b}$ \\
\hline \multicolumn{5}{|c|}{ Effect of spraying hydrogen cyanamide $\left(\mathrm{H}_{2} \mathrm{CN}_{2}\right)$ and garlic extract $(\mathrm{GE})$} \\
\hline Control & $72.73 \mathrm{e}$ & $73.34 \mathrm{~d}$ & $112.53 \mathrm{a}$ & $119.38 \mathrm{a}$ \\
\hline $\mathrm{H}_{2} \mathrm{CN}_{2}(3 \%)$ & $76.78 \mathrm{~d}$ & $77.80 \mathrm{c}$ & $83.05 \mathrm{~b}$ & $89.87 \mathrm{~b}$ \\
\hline $\mathrm{H}_{2} \mathrm{CN}_{2}(5 \%)$ & $77.82 \mathrm{c}$ & $78.74 \mathrm{~b}$ & $81.37 \mathrm{c}$ & $86.71 \mathrm{c}$ \\
\hline GE (3\%) & $78.42 b$ & $79.37 \mathrm{~b}$ & $80.99 \mathrm{c}$ & $86.40 \mathrm{c}$ \\
\hline GE $(5 \%)$ & $79.93 \mathrm{a}$ & $80.79 \mathrm{a}$ & $79.35 \mathrm{~d}$ & $84.90 \mathrm{~d}$ \\
\hline
\end{tabular}

The interaction between spraying dates (D) and hydrogen cyanamide $\left(\mathrm{H}_{2} \mathrm{CN}_{2}\right)$ and garlic extract (GE)

\begin{tabular}{|c|c|c|c|c|c|}
\hline \multirow{2}{*}{ Date } & \multirow{2}{*}{ Treatments } & \multicolumn{2}{|c|}{ Bud burst (\%) } & \multicolumn{2}{|c|}{$\begin{array}{l}\text { Time length for blooming } \\
\text { (No. of days from spraying) }\end{array}$} \\
\hline & & $\begin{array}{c}\text { Season } \\
2016\end{array}$ & $\begin{array}{c}\text { Season } \\
2017\end{array}$ & $\begin{array}{c}\text { Season } \\
2016\end{array}$ & $\begin{array}{c}\text { Season } \\
2017\end{array}$ \\
\hline \multirow[t]{5}{*}{$\mathbf{D}_{1}$} & Control & $73.00 \mathrm{i}$ & $73.16 \mathrm{j}$ & $112.67 \mathrm{a}$ & $119.24 a$ \\
\hline & $\mathrm{H}_{2} \mathrm{CN}_{2}(3 \%)$ & 73.53hi & $74.83 \mathrm{ghi}$ & $109.81 b$ & $115.64 b$ \\
\hline & $\mathrm{H}_{2} \mathrm{CN}_{2}(5 \%)$ & $74.24 \mathrm{gh}$ & $75.16 \mathrm{gh}$ & $108.12 \mathrm{c}$ & $112.21 \mathrm{c}$ \\
\hline & GE $(3 \%)$ & $74.12 \mathrm{fg}$ & $75.50 \mathrm{fg}$ & $107.47 \mathrm{c}$ & $112.33 \mathrm{c}$ \\
\hline & GE $(5 \%)$ & $75.47 \mathrm{ef}$ & $76.17 \mathrm{ef}$ & $104.33 d$ & $110.25 \mathrm{~d}$ \\
\hline \multirow[t]{5}{*}{$\mathbf{D}_{2}$} & Control & $72.76 \mathrm{i}$ & $73.50 \mathrm{ij}$ & $112.35 \mathrm{a}$ & $119.43 a$ \\
\hline & $\mathrm{H}_{2} \mathrm{CN}_{2}(3 \%)$ & $80.65 c$ & $81.14 \mathrm{c}$ & $63.58 \mathrm{~h}$ & $70.57 \mathrm{~h}$ \\
\hline & $\mathrm{H}_{2} \mathrm{CN}_{2}(5 \%)$ & $81.58 b$ & $82.53 b$ & $61.01 \mathrm{i}$ & $66.75 \mathrm{i}$ \\
\hline & GE $(3 \%)$ & $82.91 b$ & $83.16 b$ & $61.25 \mathrm{ij}$ & $66.33 \mathrm{i}$ \\
\hline & GE (5\%) & $84.47 \mathrm{a}$ & $85.28 \mathrm{a}$ & $60.34 \mathrm{j}$ & $64.13 \mathrm{j}$ \\
\hline \multirow[t]{5}{*}{$\mathbf{D}_{3}$} & Control & $72.43 \mathrm{i}$ & 73.36hij & $112.57 \mathrm{a}$ & $119.47 \mathrm{a}$ \\
\hline & $\mathrm{H}_{2} \mathrm{CN}_{2}(3 \%)$ & $76.17 \mathrm{e}$ & $77.45 \mathrm{e}$ & $75.77 \mathrm{e}$ & $83.41 \mathrm{e}$ \\
\hline & $\mathrm{H}_{2} \mathrm{CN}_{2}(5 \%)$ & $77.64 d$ & $78.53 \mathrm{~d}$ & $75.00 \mathrm{ef}$ & $81.18 \mathrm{f}$ \\
\hline & GE $(3 \%)$ & $78.23 \mathrm{~d}$ & $79.46 \mathrm{~d}$ & $74.27 f$ & $80.56 f$ \\
\hline & GE $(5 \%)$ & $79.86 \mathrm{c}$ & $80.92 c$ & $73.38 \mathrm{~g}$ & $77.34 \mathrm{~g}$ \\
\hline
\end{tabular}

Means having the same letter(s) in each column of first factor, second factor or interaction are not significantly different at $5 \%$ level. $\mathrm{D}_{1}=$ the first of December, $\mathrm{D}_{2}=$ mid of December and $\mathrm{D}_{3}=$ the end of December. *While, cont.= sprayed with tap water, $\mathrm{H}_{2} \mathrm{CN}_{2}(3 \%)$ hydrogen cyanamide $(3 \%), \mathrm{H}_{2} \mathrm{CN}_{2}(5 \%)=$ hydrogen cyanamide $(5 \%)$, GE $(3 \%)=$ garlic extract $(3 \%)$ and $\mathrm{GE}(5 \%)=$ garlic extract $(5 \%)$. 
Whoever, $\mathrm{D}_{1}$ produced the longest time length for blooming in both seasons. In addition, $\mathrm{D}_{2}$ gave the shortest time length for blooming in both seasons. Whoever $\mathrm{D}_{1}$ produced the lowest bud burst percentage in both seasons. Furthermore, $\mathrm{D}_{2}$ gave the highest bud burst percentage in both seasons. In addition, bud burst and time length for blooming were significantly affected by all treatments in both seasons. However, spraying 5\% GE gave the highest bud burst $\left(79.93 \%\right.$ in the $1^{\text {st }}$ and $80.79 \%$ in the $2^{\text {nd }}$ season) and the lowest time length for blooming (79.35 date and 84.90 date in the first and second seasons, respectively).

The obtained data from the interaction between spraying dates (D), $\mathrm{H}_{2} \mathrm{CN}_{2}$ and GE cleared that, 5\% GE with $\mathrm{D}_{2}$ recorded the highest bud burst percentage and the lowest time length for blooming in both seasons. While the three control spraying dates recorded the lowest bud burst percentage and the longest time length for blooming in both seasons.

These results mean that grapevine reached full bloom in response to 5\% GE earlier than control. This proves that full bloom of grapevine was advanced with increasing GE on $\mathrm{D}_{2}$. The earliness of flowering of vines sprayed with GE at a high concentration may be explained due to the advance of bud break and consequently advance of full bloom, coinciding with that observation by Hosoki et al. (1984), who found that fresh garlic paste resulted in early flowering of peony tree (Paeonia suffruticosa), when applied to dormant buds. Garlic extract has presence of active substances [i.e. sulphur and allyl group $\left(\mathrm{H}_{2} \mathrm{CHCH}_{2}\right)$, mainly diallyl disulfide, which is the most abundant sulphate in garlic] (Kubota and Miyamuki, 1992). In addition, Pinto et al. (2007) stated that GE breaking of dormancy in temperate fruits, i.e. through oxidative stress; through accumulating $\mathrm{H}_{2} \mathrm{O}_{2}$ and thus with the possibility for promising results in flowering plants.

These results also agree those of Serag El- Deen (2002) and Botelho et al. (2007) on grapevine, Botelho and Müller (2007) on apple, Kim and Kim (1999 and 2000) on grapevines, Mostafa and El-Yazal (2013) on apple, Botelho and Müller (2007 a and b) on apple, Jullyanna et al. (2016) on grapevines and Arispuro et al. (2008) on grapes cv. They clearly showed that GEs hastened bud break and very effective in hastening flowering and enhanced date of floral bud break and increased percentage of bud break.

\section{Leaves Number, Leaf Area and Chlorophyll Content}

Data presented in table (5) show that leaves number, leaf area and chlorophyll content were affected significantly by the three dates of spraying in both seasons. However, $\mathrm{D}_{2}$ produced the highest leaves number, leaf area and chlorophyll content in both seasons. In addition, $\mathrm{D}_{1}$ was the lowest in leaves number, leaf area and total chlorophyll content in both seasons.

Egyptian J. Desert Res., 68, No. 2, 199-222 (2018) 
Table (5). Effect of spray in three times (D) with hydrogen cyanamide $\left(\mathrm{H}_{2} \mathrm{CN}_{2}\right)$ and garlic extract (GE) on leaves number, leaf area and total chlorophyll content in Flame Seedless grapevine at 2016 and 2017.

\begin{tabular}{|c|c|c|c|c|c|c|}
\hline \multirow{2}{*}{ Treatments } & \multicolumn{2}{|c|}{$\begin{array}{l}\text { Number of leaves } \\
\text { per new shoot }\end{array}$} & \multicolumn{2}{|c|}{ Leaf area $\left(\mathrm{cm}^{2}\right)$} & \multicolumn{2}{|c|}{$\begin{array}{l}\text { Total chlorophyll } \\
\text { content (SPAD) }\end{array}$} \\
\hline & $\begin{array}{c}\text { Season } \\
2016\end{array}$ & $\begin{array}{c}\text { Season } \\
2017 \\
\end{array}$ & $\begin{array}{l}\text { Season } \\
2016\end{array}$ & $\begin{array}{c}\text { Season } \\
2017\end{array}$ & $\begin{array}{c}\text { Season } \\
2016\end{array}$ & $\begin{array}{c}\text { Season } \\
2017\end{array}$ \\
\hline \multicolumn{7}{|c|}{ Effect of date spraying (D) } \\
\hline $\mathbf{D}_{1}$ & $35.89 \mathrm{c}$ & $36.24 \mathrm{c}$ & $123.89 \mathrm{c}$ & $125.02 \mathrm{c}$ & $33.58 \mathrm{c}$ & $34.65 \mathrm{c}$ \\
\hline $\mathbf{D}_{2}$ & $41.46 \mathrm{a}$ & $42.49 \mathrm{a}$ & $128.07 \mathrm{a}$ & $129.01 \mathrm{a}$ & $37.46 \mathrm{a}$ & $38.81 \mathrm{a}$ \\
\hline $\mathbf{D}_{3}$ & $37.97 \mathrm{~b}$ & $38.43 \mathrm{~b}$ & $126.01 \mathrm{~b}$ & $126.67 \mathrm{~b}$ & $35.06 \mathrm{~b}$ & $36.63 \mathrm{~b}$ \\
\hline \multicolumn{7}{|c|}{ Effect of spraying hydrogen cyanamide $\left(\mathrm{H}_{2} \mathrm{CN}_{2}\right)$ and garlic extract (GE) } \\
\hline Control & $32.74 \mathrm{e}$ & $33.39 \mathrm{e}$ & $122.04 d$ & $122.72 \mathrm{~d}$ & $32.55 d$ & $33.59 \mathrm{~d}$ \\
\hline $\mathrm{H}_{2} \mathrm{CN}_{2}(3 \%)$ & $38.31 \mathrm{~d}$ & $38.78 \mathrm{~d}$ & $126.21 \mathrm{c}$ & $127.37 \mathrm{c}$ & $35.22 \mathrm{c}$ & $36.53 \mathrm{c}$ \\
\hline $\mathrm{H}_{2} \mathrm{CN}_{2}(5 \%)$ & $39.40 \mathrm{c}$ & $40.01 \mathrm{c}$ & $126.74 \mathrm{~b}$ & $127.82 \mathrm{~b}$ & $35.65 \mathrm{c}$ & $36.95 \mathrm{c}$ \\
\hline GE (3\%) & $40.36 \mathrm{~b}$ & $41.21 \mathrm{~b}$ & $127.19 \mathrm{~b}$ & $127.05 \mathrm{~b}$ & $36.52 \mathrm{~b}$ & $37.80 \mathrm{~b}$ \\
\hline GE (5\%) & $41.44 \mathrm{a}$ & $41.88 \mathrm{a}$ & $127.77 \mathrm{a}$ & $128.55 \mathrm{a}$ & $37.89 \mathrm{a}$ & $38.62 \mathrm{a}$ \\
\hline
\end{tabular}

The interaction between spraying dates (D) and hydrogen cyanamide $\left(\mathrm{H}_{2} \mathrm{CN}_{2}\right)$ and garlic extract (GE)

\begin{tabular}{|c|c|c|c|c|c|c|c|}
\hline \multirow{2}{*}{ Date } & \multirow{2}{*}{ Treatments } & \multicolumn{2}{|c|}{$\begin{array}{c}\text { Number of leaves } \\
\text { per new shoot }\end{array}$} & \multicolumn{2}{|c|}{ Leaf area $\left(\mathrm{cm}_{2}\right)$} & \multicolumn{2}{|c|}{$\begin{array}{l}\text { Total chlorophyll } \\
\text { content (SPAD) }\end{array}$} \\
\hline & & $\begin{array}{c}\text { Season } \\
2016\end{array}$ & $\begin{array}{c}\text { Season } \\
2017\end{array}$ & $\begin{array}{c}\text { Season } \\
2016\end{array}$ & $\begin{array}{c}\text { Season } \\
2017\end{array}$ & $\begin{array}{c}\text { Season } \\
2016\end{array}$ & $\begin{array}{c}\text { Season } \\
2017\end{array}$ \\
\hline \multirow[t]{5}{*}{$\mathbf{D}_{1}$} & Control & $33.45 \mathrm{k}$ & $33.67 \mathrm{j}$ & $121.45 \mathrm{i}$ & $122.65 j$ & $32.85 \mathrm{j}$ & $33.80 \mathrm{~h}$ \\
\hline & $\mathrm{H}_{2} \mathrm{CN}_{2}(3 \%)$ & $35.17 \mathrm{j}$ & $35.66 \mathrm{i}$ & $122.47 \mathrm{~h}$ & $123.79 \mathrm{i}$ & $33.00 \mathrm{ij}$ & $34.23 \mathrm{~h}$ \\
\hline & $\mathrm{H}_{2} \mathrm{CN}_{2}(5 \%)$ & $36.22 \mathrm{ij}$ & $36.67 \mathrm{~h}$ & $124.23 \mathrm{~g}$ & $125.53 \mathrm{~h}$ & $33.83 \mathrm{hi}$ & $34.47 \mathrm{gh}$ \\
\hline & GE (3\%) & $36.77 \mathrm{hi}$ & $37.33 \mathrm{gh}$ & $125.00 \mathrm{~g}$ & $125.88 \mathrm{gh}$ & $34.00 \mathrm{gh}$ & $35.33 \mathrm{fg}$ \\
\hline & GE $(5 \%)$ & $37.85 \mathrm{gh}$ & $38.00 \mathrm{~g}$ & $126.33 \mathrm{ef}$ & $127.27 \mathrm{ef}$ & $34.23 \mathrm{fg}$ & $35.46 \mathrm{ef}$ \\
\hline \multirow[t]{5}{*}{$\mathbf{D}_{2}$} & Control & $32.66 \mathrm{kl}$ & $33.33 \mathrm{j}$ & $122.25 \mathrm{hi}$ & $122.93 \mathrm{ij}$ & $32.10 \mathrm{j}$ & $33.57 \mathrm{~h}$ \\
\hline & $\mathrm{H}_{2} \mathrm{CN}_{2}(3 \%)$ & $41.67 \mathrm{~d}$ & $42.00 \mathrm{~d}$ & $128.18 \mathrm{~cd}$ & $129.46 \mathrm{~cd}$ & $37.41 \mathrm{c}$ & $38.80 \mathrm{c}$ \\
\hline & $\mathrm{H}_{2} \mathrm{CN}_{2}(5 \%)$ & $43.33 \mathrm{c}$ & $44.00 \mathrm{c}$ & $129.00 \mathrm{bc}$ & $129.98 \mathrm{bc}$ & $38.00 \mathrm{c}$ & $39.56 \mathrm{c}$ \\
\hline & GE (3\%) & $44.32 b$ & $45.66 \mathrm{~b}$ & $129.92 b$ & $130.90 \mathrm{~b}$ & $39.57 b$ & $40.35 b$ \\
\hline & GE $(5 \%)$ & $45.47 \mathrm{a}$ & $47.33 \mathrm{a}$ & $131.00 \mathrm{a}$ & $131.78 \mathrm{a}$ & $40.23 \mathrm{a}$ & $41.78 \mathrm{a}$ \\
\hline \multirow[t]{5}{*}{$\mathbf{D}_{3}$} & Control & 32.111 & $33.33 \mathrm{j}$ & $122.42 \mathrm{hi}$ & $122.58 \mathrm{ij}$ & $32.71 \mathrm{j}$ & $33.42 \mathrm{~h}$ \\
\hline & $\mathrm{H}_{2} \mathrm{CN}_{2}(3 \%)$ & $38.10 \mathrm{fg}$ & $38.33 \mathrm{~g}$ & $128.00 \mathrm{~d}$ & $128.87 \mathrm{~d}$ & $35.25 \mathrm{ef}$ & 36.58de \\
\hline & $\mathrm{H}_{2} \mathrm{CN}_{2}(5 \%)$ & $38.67 \mathrm{f}$ & $39.33 \mathrm{f}$ & $127.00 \mathrm{e}$ & $127.97 \mathrm{e}$ & $35.13 \mathrm{e}$ & $36.82 \mathrm{~d}$ \\
\hline & GE $(3 \%)$ & $40.00 \mathrm{e}$ & $40.33 \mathrm{e}$ & $126.67 \mathrm{ef}$ & $127.37 \mathrm{ef}$ & $36.00 \mathrm{de}$ & $37.73 \mathrm{~d}$ \\
\hline & GE $(5 \%)$ & $41.00 \mathrm{~d}$ & $40.67 \mathrm{e}$ & $126.00 \mathrm{f}$ & $126.60 \mathrm{fg}$ & $36.23 \mathrm{~d}$ & $38.63 \mathrm{c}$ \\
\hline
\end{tabular}

Means having the same letter(s) in each column of first factor, second factor or interaction are not significantly different at $5 \%$ level. $\mathrm{D}_{1}=$ first of December, $\mathrm{D}_{2}=$ mid of December and $\mathrm{D}_{3}=$ end of December. *While, cont.= sprayed with tap water, $\mathrm{H}_{2} \mathrm{CN}_{2}(3 \%)=$ hydrogen cyanamide $(3 \%)$, $\mathrm{H}_{2} \mathrm{CN}_{2}(5 \%)=$ hydrogen cyanamide $(5 \%)$, GE $(3 \%)=$ garlic extract $(3 \%)$ and $\mathrm{GE}(5 \%)=$ garlic extract $(5 \%)$.

Egyptian J. Desert Res., 68, No. 2, 199-222 (2018) 
In addition, leaves number, leaf area and chlorophyll content were significantly affected by all treatments in both seasons. However, spraying $5 \%$ GE gave the best leaves number (41.44 in the $1^{\text {st }}$ and 41.88 in the $2^{\text {nd }}$ season), leaf area (127.77 and $128.55 \mathrm{~cm}^{2}$ in the first and second seasons, respectively) and leaf chlorophyll content (37.89 in the $1^{\text {st }}$ and 38.62 in the $2^{\text {nd }}$ season) and 3\% GE comes the second in both seasons.

Furthermore, the interaction between spraying dates (D), $\mathrm{H}_{2} \mathrm{CN}_{2}$ and GE cleared that, $5 \% \mathrm{GE}$ with $\mathrm{D}_{2}$ recorded the highest values of leaves number, leaf area and leaf chlorophyll content in both seasons. While control recorded the lowest leaves number, leaf area and leaf chlorophyll content in both seasons.

These results are in agreement with those of Botelho and Müller (2007 a and b) on apple, El-Desouky et al. (1998) and Wanas et al. (1998) on squash, Sheren and Eman (2015) on pear, El-Sharony et al (2015) on mango and El-Salhy et al. (2017) on grapevines. The previous investigators found that GE enhanced vegetative growth.

\section{Harvest Date}

It was obvious when measuring ripening stage that there were clear differences between harvests dates for each treatment under the same date of spray, so that harvest of each treatment according to ripening date detected in an interactions table.

Data in table (6) and fig (1) present that spraying 5\% GE on midDecember $\left(\mathrm{D}_{2}\right)$ resulted in the earliest harvest date in both seasons, followed by spraying $3 \% \mathrm{GE}$ and $5 \% \mathrm{H}_{2} \mathrm{CN}_{2}$ on $\mathrm{D}_{2}$ in both seasons. In addition, spraying $5 \%$ GE on $\mathrm{D}_{3}$ comes after $\mathrm{D}_{2}$. Generally, spraying $\mathrm{D}_{1}$ was the later in harvest date as compared with the other two times in both seasons.

It is obvious from the obtained results that increasing GE concentration was positively related with an advance in harvest time. These results are in agreement with those found by Serag El-Deen (2002), who mentioned that 10 and $20 \%$ GE application were significantly effective in advancing harvesting date of Thompson seedless grape than the control. Kubota et al. (2000) found that GE advanced bud break of grapevines ('Pione' and 'Thompson Seedless') significantly and caused uniformity in bud break, but the effectiveness varied according to the concentration. The GE showed a great potential for bud break in organic production presenting similar effects of cyanamides in bud break and garlic extract improved the sprouting percentage, number of clusters, accelerated the beginning of sprouting and reduced the cycle between pruning and harvest in grape (Botelho et al., 2010).

Egyptian J. Desert Res., 68, No. 2, 199-222 (2018) 
Table (6). Effect of spray in three times (D) with hydrogen cyanamide $\left(\mathrm{H}_{2} \mathrm{CN}_{2}\right)$ and garlic extract $(\mathrm{GE})$ on harvest day in Flame Seedless grapevine at 2016 and 2017.

\begin{tabular}{lcccccc}
\hline Date & $\left.\mathbf{( D}_{\mathbf{1}}\right)$ & $\left.\mathbf{( D}_{\mathbf{1}}\right)$ & $\left.\mathbf{( D}_{2}\right)$ & $\left.\mathbf{( D}_{\mathbf{2}}\right)$ & $\left.\mathbf{( D}_{\mathbf{3}}\right)$ & $\left.\mathbf{( D}_{\mathbf{3}}\right)$ \\
Treatments & $\mathbf{2 0 1 6}$ & $\mathbf{2 0 1 7}$ & $\mathbf{2 0 1 6}$ & $\mathbf{2 0 1 7}$ & $\mathbf{2 0 1 6}$ & $\mathbf{2 0 1 7}$ \\
\hline Control & 01-Jul & 05-Jul & 01-Jul & 01-Jul & 01-Jul & 01-Jul \\
$\mathbf{H}_{\mathbf{2}} \mathbf{C N}_{\mathbf{2}} \mathbf{( 3 \% )}$ & 28-Jun & 30-Jun & 16-May & 20-May & 05-Jun & 12-Jun \\
$\mathbf{H}_{\mathbf{2}} \mathbf{C N}_{\mathbf{2}} \mathbf{( 5 \% )}$ & 18-Jun & 22-Jun & 14-May & 19-May & 04-Jun & 10-Jun \\
$\mathbf{G E ~ ( 3 \% ) ~}$ & 17-Jun & 22-Jun & 14-May & 19-May & 04-Jun & 10-Jun \\
$\mathbf{G E ~ ( 5 \% ) ~}$ & 15-Jun & 20-Jun & 12-May & 17-May & 01-Jun & 07-Jun \\
\hline
\end{tabular}

$\mathrm{D}_{1}=$ first of December, $\mathrm{D}_{2}=$ mid of December and $\mathrm{D}_{3}=$ end of December. ${ }^{*}$ While, control= sprayed with tap water, $\mathrm{H}_{2} \mathrm{CN}_{2}(3 \%)=$ hydrogen cyanamide $(3 \%), \mathrm{H}_{2} \mathrm{CN}_{2}(5 \%)$ = hydrogen cyanamide $(5 \%)$, GE $(3 \%)=$ garlic extract $(3 \%)$ and $\mathrm{GE}(5 \%)=$ garlic extract $(5 \%)$.

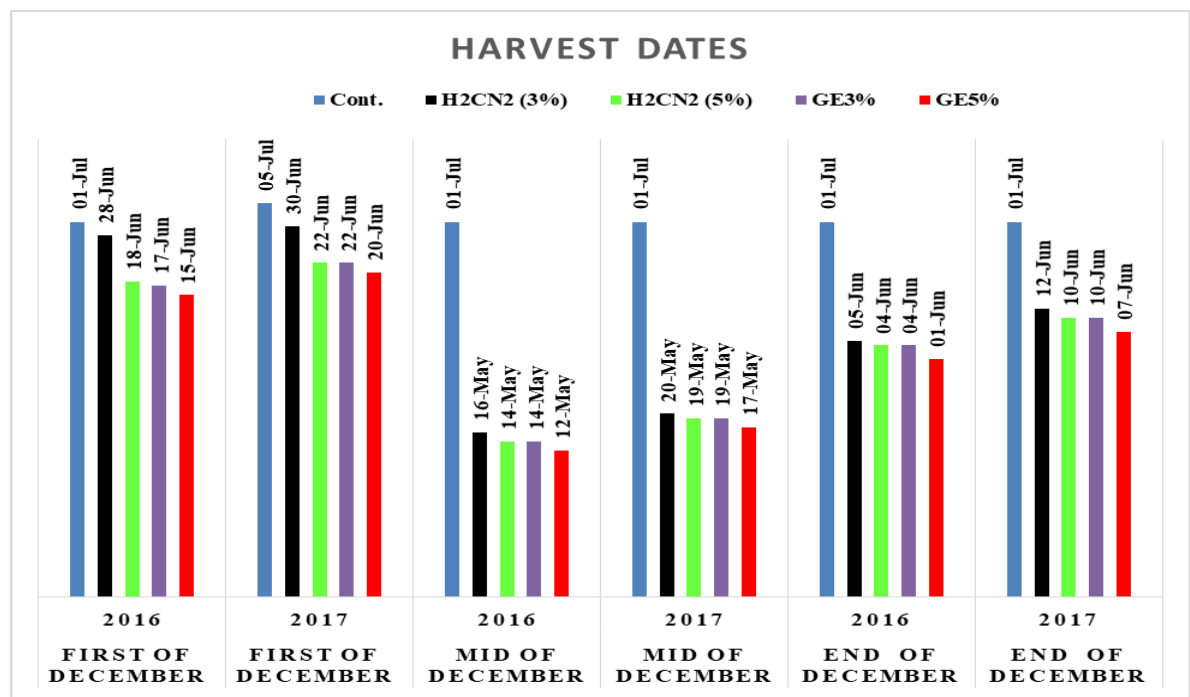

Fig. (1). Effect of spray in three times (D) with hydrogen cyanamide $\left(\mathrm{H}_{2} \mathrm{CN}_{2}\right)$ and garlic extract (GE) on harvest day in Flame Seedless grapevine at 2016 and 2017.

\section{Cluster Weight, Number and Yield}

Concerning the results in table (7), cluster weight, cluster number and yield were significantly affected by the three dates of spraying in both seasons. Whoever, $\mathrm{D}_{2}$ produced the highest cluster weight $(574.17 \mathrm{~g}$ in the $1^{\text {st }}$ and $690.74 \mathrm{~g}$ in the $2^{\text {nd }}$ season), cluster number (31.66 in the $1^{\text {st }}$ and 32.11 in the $2^{\text {nd }}$ season) and yield (17.64 kg and $18.08 \mathrm{~kg}$ in the first and second seasons, respectively). While, $\mathrm{D}_{1}$ was the lowest in cluster weight $(432.76 \mathrm{~g}$ in the $1^{\text {st }}$ and $443.54 \mathrm{~g}$ in the $2^{\text {nd }}$ season), cluster number $\left(25.00\right.$ in the $1^{\text {st }}$ and 
$25.47 \mathrm{in}$ the $2^{\text {nd }}$ season) and yield $\left(10.93 \mathrm{~kg}\right.$ in the $1^{\text {st }}$ and $11.36 \mathrm{~kg}$ in the $2^{\text {nd }}$ season).

Cluster weight, cluster number and yield were significantly affected by all treatments in both seasons. However, spraying 5\% GE resulted in the best cluster weight, number and yield in both seasons. On the other side, control was significantly the lowest in cluster weight, cluster number and yield in both seasons. Furthermore, the obtained data from the interaction between spraying dates (D), $\mathrm{H}_{2} \mathrm{CN}_{2}$ and GE cleared that, 5\% GE with $\mathrm{D}_{2}$ recorded the highest cluster weight, cluster number and yield in both seasons. While control with the three dates of spraying recorded the lowest cluster weight, number and yield in both seasons.

The beneficial effects of GE on breaking bud-endo-dormancy, promoting the growth and yield (Tables 5 and 7) of grapevines might be attributed to their higher content of sulfur containing compounds, amino acids and various volatiles. Sulfur in constitute of the three amino acids cystene, cysteine and methionine and hence proteins. They play definite roles in enhancing the biosynthesis of $\mathrm{GA}_{3}$, indoles, free water, total carbohydrates and most organic foods and reducing phenols and ABA (Kubota et al., 1999 and 2000).

The obtained results agree with El-Desouky et al. (1998) and Wanas et al. (1998) on squash plant, Serag El-Deen (2002) on 'Thompson seedless' grapes, Chowdhury et al. (2007) on mango, Botelho et al. (2010) on grape, Abd El-Razek et al. (2013) on 'Le Conte' pear and Mostafa and El-Yazal (2013) on "Anna" apple. They found that the natural extract of garlic cloves improve growth, fruit yield and the quality of such product.

\section{Weight and Volume of 100 Berries}

It is evident from the data in table (8), that weight and volume of 100 berries were affected significantly by the three dates of spraying in both seasons. Whoever, $\mathrm{D}_{2}$ produced the highest weight and volume of 100 berries in both seasons. In addition, $\mathrm{D}_{1}$ was the lowest in weight and volume of 100 berries in both seasons.

In addition, the weight and volume of 100 berries was significantly affected by all treatments in both seasons. However, spraying 5\% GE gave the best weight of 100 berries (276.89 $\mathrm{g}$ in the $1^{\text {st }}$ and $287.22 \mathrm{~g}$ in the $2^{\text {nd }}$ season) and the best volume of 100 berries $\left(259.88 \mathrm{~cm}^{3}\right.$ in the $1^{\text {st }}$ and $270.36 \mathrm{~cm}^{3}$ in the $2^{\text {nd }}$ season), while $3 \% \mathrm{GE}$ in both seasons comes after.

The obtained data from the interaction between date of spraying (D), $\mathrm{H}_{2} \mathrm{CN}_{2}$ and GE showed that, 5\% GE with $\mathrm{D}_{2}$ recorded the highest values of weight and volume of 100 berries in both seasons. While control on the three spraying date recorded the lowest weight and volume of 100 berries in both seasons.

Egyptian J. Desert Res., 68, No. 2, 199-222 (2018) 
Table (7). Effect of spray in three times (D) with hydrogen cyanamide $\left(\mathrm{H}_{2} \mathrm{CN}_{2}\right)$ and garlic extract (GE) on cluster weight, number and yield in flame seedless grapevine at 2016 and 2017

\begin{tabular}{|c|c|c|c|c|c|c|c|}
\hline \multicolumn{2}{|c|}{ Parameters } & \multicolumn{2}{|c|}{ Cluster weight (g) } & \multicolumn{2}{|c|}{ Cluster number } & \multicolumn{2}{|c|}{ Yield (kg) } \\
\hline \multicolumn{2}{|c|}{ Treatments } & $\begin{array}{l}\text { Season } \\
2016\end{array}$ & $\begin{array}{c}\text { Season } \\
2017\end{array}$ & $\begin{array}{c}\text { Season } \\
2016\end{array}$ & $\begin{array}{l}\text { Season } \\
2017\end{array}$ & $\begin{array}{c}\text { Season } \\
2016\end{array}$ & $\begin{array}{c}\text { Season } \\
2017\end{array}$ \\
\hline \multicolumn{8}{|c|}{ Effect of date spraying (D) } \\
\hline \multicolumn{2}{|c|}{$\mathbf{D}_{1}$} & $432.76 \mathrm{c}$ & $443.54 \mathrm{c}$ & $25.00 \mathrm{c}$ & $25.47 \mathrm{c}$ & $10.93 \mathrm{c}$ & $11.36 \mathrm{c}$ \\
\hline \multicolumn{2}{|l|}{$\mathbf{D}_{2}$} & $546.15 \mathrm{a}$ & $555.12 \mathrm{a}$ & $31.66 \mathrm{a}$ & $32.11 \mathrm{a}$ & $17.64 \mathrm{a}$ & $18.08 \mathrm{a}$ \\
\hline \multicolumn{2}{|l|}{$\mathbf{D}_{3}$} & $506.29 \mathrm{~b}$ & $517.06 \mathrm{~b}$ & $27.22 b$ & $27.84 \mathrm{~b}$ & $14.03 \mathrm{~b}$ & $14.49 \mathrm{~b}$ \\
\hline \multicolumn{8}{|c|}{ Effect of spraying hydrogen cyanamide $\left(\mathrm{H}_{2} \mathrm{CN}_{2}\right)$ and garlic extract (GE) } \\
\hline \multicolumn{2}{|c|}{ Control } & $387.48 \mathrm{e}$ & $394.22 \mathrm{e}$ & $23.61 \mathrm{e}$ & $24.14 \mathrm{e}$ & $9.21 \mathrm{e}$ & $9.50 \mathrm{e}$ \\
\hline \multicolumn{2}{|c|}{$\mathrm{H}_{2} \mathrm{CN}_{2}(3 \%)$} & $493.50 \mathrm{~d}$ & $505.32 d$ & $27.60 d$ & $28.00 \mathrm{~d}$ & $13.89 \mathrm{~d}$ & $14.23 \mathrm{~d}$ \\
\hline \multicolumn{2}{|c|}{$\mathrm{H}_{2} \mathrm{CN}_{2}(5 \%)$} & $515.31 \mathrm{c}$ & $525.78 \mathrm{c}$ & $28.46 \mathrm{c}$ & $29.02 \mathrm{c}$ & $14.94 \mathrm{c}$ & $15.43 \mathrm{c}$ \\
\hline \multicolumn{2}{|c|}{ GE (3\%) } & $529.64 b$ & $540.63 b$ & $29.29 b$ & $30.04 \mathrm{~b}$ & $15.90 \mathrm{~b}$ & $16.40 \mathrm{~b}$ \\
\hline \multicolumn{2}{|c|}{ GE $(5 \%)$} & $549.41 \mathrm{a}$ & $560.05 \mathrm{a}$ & $30.84 a$ & $31.18 \mathrm{a}$ & $17.07 \mathrm{a}$ & $17.58 \mathrm{a}$ \\
\hline \multicolumn{8}{|c|}{$\begin{array}{l}\text { The interaction between spraying dates }(\mathrm{D}) \text { and hydrogen cyanamide }\left(\mathrm{H}_{2} \mathrm{CN}_{2}\right) \text { and } \\
\text { garlic extract (GE) }\end{array}$} \\
\hline \multirow[b]{2}{*}{ Date } & \multirow[b]{2}{*}{ Treatments } & \multicolumn{2}{|c|}{ Cluster weight (g) } & \multicolumn{2}{|c|}{ Cluster number } & \multicolumn{2}{|c|}{ Yield (kg) } \\
\hline & & $\begin{array}{c}\text { Season } \\
2016\end{array}$ & $\begin{array}{c}\text { Season } \\
2017\end{array}$ & $\begin{array}{c}\text { Season } \\
2016\end{array}$ & $\begin{array}{c}\text { Season } \\
2017\end{array}$ & $\begin{array}{c}\text { Season } \\
2016\end{array}$ & $\begin{array}{c}\text { Season } \\
2017\end{array}$ \\
\hline \multirow[t]{5}{*}{$\mathbf{D}_{1}$} & Control & $387.21 \mathrm{~m}$ & $397.71 \mathrm{~m}$ & $23.58 \mathrm{k}$ & $24.11 \mathrm{~h}$ & $9.16 \mathrm{~m}$ & 9.541 \\
\hline & $\mathrm{H}_{2} \mathrm{CN}_{2}(3 \%)$ & 405.861 & 418.471 & $24.64 \mathrm{ij}$ & $25.01 \mathrm{gh}$ & 9.991 & $10.46 \mathrm{k}$ \\
\hline & $\mathrm{H}_{2} \mathrm{CN}_{2}(5 \%)$ & $432.47 \mathrm{k}$ & $441.35 \mathrm{k}$ & $25.13 \mathrm{hi}$ & $25.27 \mathrm{~g}$ & $10.95 \mathrm{k}$ & $11.33 \mathrm{j}$ \\
\hline & GE (3\%) & $450.58 \mathrm{j}$ & $462.00 \mathrm{j}$ & $25.27 \mathrm{~h}$ & $26.00 \mathrm{fg}$ & $11.56 \mathrm{j}$ & $12.01 \mathrm{i}$ \\
\hline & GE (5\%) & $487.68 \mathrm{i}$ & $498.17 \mathrm{i}$ & $26.38 \mathrm{~g}$ & $27.00 \mathrm{ef}$ & $12.99 \mathrm{i}$ & $13.46 \mathrm{~h}$ \\
\hline \multirow[t]{5}{*}{$\mathbf{D}_{2}$} & Control & $388.00 \mathrm{~m}$ & $387.28 \mathrm{~m}$ & $24.00 \mathrm{jk}$ & $24.31 \mathrm{~h}$ & $9.31 \mathrm{~m}$ & 9.421 \\
\hline & $\mathrm{H}_{2} \mathrm{CN}_{2}(3 \%)$ & $574.47 \mathrm{~d}$ & $585.78 \mathrm{~d}$ & $31.18 \mathrm{c}$ & $31.78 \mathrm{c}$ & $18.18 d$ & $18.54 d$ \\
\hline & $\mathrm{H}_{2} \mathrm{CN}_{2}(5 \%)$ & $580.75 \mathrm{c}$ & $593.00 \mathrm{c}$ & $33.00 \mathrm{~b}$ & $33.64 b$ & $19.16 \mathrm{c}$ & $19.76 \mathrm{c}$ \\
\hline & GE $(3 \%)$ & $587.34 \mathrm{~b}$ & $598.00 \mathrm{~b}$ & $34.34 \mathrm{a}$ & $35.00 \mathrm{a}$ & $20.37 b$ & $20.93 b$ \\
\hline & GE $(5 \%)$ & $600.21 \mathrm{a}$ & $611.00 \mathrm{a}$ & $35.82 \mathrm{a}$ & $35.85 \mathrm{a}$ & $21.22 \mathrm{a}$ & $21.78 \mathrm{a}$ \\
\hline \multirow[t]{5}{*}{$\mathbf{D}_{3}$} & Control & $387.25 \mathrm{~m}$ & $397.68 \mathrm{~m}$ & $23.27 \mathrm{k}$ & $24.00 \mathrm{~h}$ & $9.16 \mathrm{~m}$ & 9.541 \\
\hline & $\mathrm{H}_{2} \mathrm{CN}_{2}(3 \%)$ & $500.17 \mathrm{~h}$ & $511.72 \mathrm{~h}$ & $27.00 \mathrm{fg}$ & $27.21 \mathrm{e}$ & $13.50 \mathrm{~h}$ & $13.98 \mathrm{~h}$ \\
\hline & $\mathrm{H}_{2} \mathrm{CN}_{2}(5 \%)$ & $532.72 \mathrm{~g}$ & $543.00 \mathrm{~g}$ & $27.26 f$ & $28.17 \mathrm{de}$ & $14.73 \mathrm{~g}$ & $15.20 \mathrm{~g}$ \\
\hline & GE (3\%) & $551.00 \mathrm{f}$ & $561.91 \mathrm{f}$ & $28.27 \mathrm{e}$ & $29.13 d$ & $15.79 \mathrm{f}$ & $16.27 f$ \\
\hline & GE (5\%) & $560.35 \mathrm{e}$ & $571.00 \mathrm{e}$ & $30.33 d$ & $30.71 \mathrm{c}$ & $17.00 \mathrm{e}$ & $17.50 \mathrm{e}$ \\
\hline
\end{tabular}

Means having the same letter(s) in each column of first factor, second factor or interaction are not significantly different at $5 \%$ level. $\mathrm{D}_{1}=$ the first of December, $\mathrm{D}_{2}=$ mid of December and $\mathrm{D}_{3}=$ the end of December. *While, control= sprayed with tap water, $\mathrm{H}_{2} \mathrm{CN}_{2}(3 \%)=$ hydrogen cyanamide $(3 \%), \mathrm{H}_{2} \mathrm{CN}_{2}(5 \%)=$ hydrogen cyanamide $(5 \%)$, GE $(3 \%)=$ garlic extract $(3 \%)$ and GE $(5 \%)=$ garlic extract $(5 \%)$. 
Table (8). Effect of spray in three times (D) with hydrogen cyanamide $\left(\mathrm{H}_{2} \mathrm{CN}_{2}\right)$ and garlic extract (GE) on weight and volume of 100 berries in flame seedless grapevine at 2016 and 2017.

\begin{tabular}{lcccc}
\hline \multirow{2}{*}{ Treatments } & \multicolumn{2}{c}{$\begin{array}{c}\text { Weight of 100 } \\
\text { berries }\end{array}$} & \multicolumn{2}{c}{ Volume of 100 berries } \\
\cline { 2 - 5 } & $\begin{array}{c}\text { Season } \\
\mathbf{2 0 1 6}\end{array}$ & $\begin{array}{c}\text { Season } \\
\mathbf{2 0 1 7}\end{array}$ & $\begin{array}{c}\text { Season } \\
\mathbf{2 0 1 6}\end{array}$ & $\begin{array}{c}\text { Season } \\
\mathbf{2 0 1 7}\end{array}$ \\
\hline Effect of date spraying $\mathbf{( D )}$ & & & \\
\hline $\mathbf{D}_{\mathbf{1}}$ & $235.43 \mathrm{c}$ & $245.77 \mathrm{c}$ & $218.17 \mathrm{c}$ & $228.53 \mathrm{c}$ \\
$\mathbf{D}_{\mathbf{2}}$ & $285.41 \mathrm{a}$ & $295.84 \mathrm{a}$ & $271.34 \mathrm{a}$ & $281.60 \mathrm{a}$ \\
$\mathbf{D}_{\mathbf{3}}$ & $257.11 \mathrm{~b}$ & $267.59 \mathrm{~b}$ & $240.18 \mathrm{~b}$ & $250.69 \mathrm{~b}$ \\
\hline
\end{tabular}

Effect of spraying hydrogen cyanamide $\left(\mathrm{H}_{2} \mathrm{CN}_{2}\right)$ and garlic extract (GE)

\begin{tabular}{lllll}
\hline Control & $228.25 \mathrm{e}$ & $238.41 \mathrm{e}$ & $212.15 \mathrm{e}$ & $222.48 \mathrm{e}$ \\
\hline $\mathbf{H}_{\mathbf{2}} \mathbf{C N}_{\mathbf{2}} \mathbf{( 3 \% )}$ & $258.52 \mathrm{~d}$ & $268.12 \mathrm{~d}$ & $241.90 \mathrm{~d}$ & $252.11 \mathrm{~d}$ \\
$\mathbf{H}_{\mathbf{2}} \mathbf{C N}_{\mathbf{2}} \mathbf{( 5 \% )}$ & $264.06 \mathrm{c}$ & $274.52 \mathrm{c}$ & $248.35 \mathrm{c}$ & $258.89 \mathrm{c}$ \\
$\mathbf{G E ~ ( 3 \% )}$ & $268.86 \mathrm{~b}$ & $279.39 \mathrm{~b}$ & $253.87 \mathrm{~b}$ & $264.18 \mathrm{~b}$ \\
$\mathbf{G E ~ ( 5 \% )}$ & $276.89 \mathrm{a}$ & $287.22 \mathrm{a}$ & $259.88 \mathrm{a}$ & $270.36 \mathrm{a}$ \\
\hline
\end{tabular}

The interaction between spraying dates (D) and hydrogen cyanamide $\left(\mathrm{H}_{2} \mathrm{CN}_{2}\right)$ and garlic extract (GE)

\begin{tabular}{|c|c|c|c|c|c|}
\hline \multirow{2}{*}{ Date } & \multirow{2}{*}{ Treatments } & \multicolumn{2}{|c|}{$\begin{array}{l}\text { Weight of } 100 \\
\text { berries }\end{array}$} & \multicolumn{2}{|c|}{ volume of 100 berries } \\
\hline & & $\begin{array}{l}\text { Season } \\
2016\end{array}$ & $\begin{array}{c}\text { Season } \\
2017\end{array}$ & $\begin{array}{c}\text { Season } \\
2016\end{array}$ & $\begin{array}{c}\text { Season } \\
2017\end{array}$ \\
\hline \multirow[t]{5}{*}{$\mathbf{D}_{1}$} & Control & 228.38 & $238.11 n$ & $212.00 \mathrm{~m}$ & $222.13 \mathrm{~m}$ \\
\hline & $\mathrm{H}_{2} \mathrm{CN}_{2}(3 \%)$ & 230.231 & 240.671 & 214.881 & 225.141 \\
\hline & $\mathrm{H}_{2} \mathrm{CN}_{2}(5 \%)$ & $234.44 \mathrm{k}$ & $245.10 \mathrm{k}$ & $218.21 \mathrm{k}$ & $229.13 \mathrm{k}$ \\
\hline & GE (3\%) & $238.43 \mathrm{j}$ & $249.00 \mathrm{j}$ & $220.65 j$ & $231.25 \mathrm{j}$ \\
\hline & GE (5\%) & $245.71 \mathrm{i}$ & $256.00 \mathrm{i}$ & $225.14 \mathrm{i}$ & $235.00 \mathrm{i}$ \\
\hline \multirow[t]{5}{*}{$\mathbf{D}_{2}$} & Control & 228.00 & $238.36 \mathrm{mn}$ & $212.33 \mathrm{~m}$ & $223.00 \mathrm{~m}$ \\
\hline & $\mathrm{H}_{2} \mathrm{CN}_{2}(3 \%)$ & $287.57 \mathrm{~d}$ & $298.22 d$ & $275.51 d$ & $285.54 d$ \\
\hline & $\mathrm{H}_{2} \mathrm{CN}_{2}(5 \%)$ & $297.23 \mathrm{c}$ & $308.14 \mathrm{c}$ & $285.43 \mathrm{c}$ & $295.34 \mathrm{c}$ \\
\hline & GE (3\%) & $303.55 \mathrm{~b}$ & $313.47 \mathrm{~b}$ & $289.26 \mathrm{~b}$ & $299.14 b$ \\
\hline & GE $(5 \%)$ & $310.73 a$ & $321.01 \mathrm{a}$ & $294.17 \mathrm{a}$ & $305.00 \mathrm{a}$ \\
\hline \multirow[t]{5}{*}{$\mathbf{D}_{3}$} & Control & 228.39 & $238.77 \mathrm{~m}$ & $212.12 \mathrm{~m}$ & $222.33 \mathrm{~m}$ \\
\hline & $\mathrm{H}_{2} \mathrm{CN}_{2}(3 \%)$ & $257.77 \mathrm{~h}$ & $268.47 \mathrm{~h}$ & $235.33 \mathrm{~h}$ & $245.67 \mathrm{~h}$ \\
\hline & $\mathrm{H}_{2} \mathrm{CN}_{2}(5 \%)$ & $260.53 \mathrm{~g}$ & $270.34 \mathrm{~g}$ & $241.43 \mathrm{~g}$ & $252.22 \mathrm{~g}$ \\
\hline & GE $(3 \%)$ & $264.62 \mathrm{f}$ & $275.72 \mathrm{f}$ & $251.71 \mathrm{f}$ & $262.15 \mathrm{f}$ \\
\hline & GE (5\%) & $274.24 \mathrm{e}$ & $284.67 \mathrm{e}$ & $260.34 \mathrm{e}$ & $271.10 \mathrm{e}$ \\
\hline
\end{tabular}

Means having the same letter(s) in each column of first factor, second factor or interaction are not significantly different at $5 \%$ level. $\mathrm{D}_{1}=$ the first of December, $\mathrm{D}_{2}=$ mid of December and $\mathrm{D}_{3}=$ the end of December. *While, control= sprayed with tap water, $\mathrm{H}_{2} \mathrm{CN}_{2}(3 \%)=$ hydrogen cyanamide $(3 \%), \mathrm{H}_{2} \mathrm{CN}_{2}(5 \%)=$ hydrogen cyanamide $(5 \%)$, GE $(3 \%)=$ garlic extract $(3 \%)$ and GE $(5 \%)=$ garlic extract $(5 \%)$.

Egyptian J. Desert Res., 68, No. 2, 199-222 (2018) 


\section{Cluster Length, Width, Berry Length and Diameter}

Data in table (9) clear that cluster length, width, berry length and diameter were affected significantly by the three spraying dates in both seasons. Whoever, $\mathrm{D}_{2}$ produced the highest cluster length, width, berry length and diameter in both seasons. In addition, $\mathrm{D}_{1}$ was the lowest in cluster length, width, berry length and diameter both seasons

In addition, cluster length, width, berry length and diameter were significantly affected by all treatments in both seasons. However, spraying $5 \%$ GE gave the best cluster length $\left(23.12 \mathrm{~cm}\right.$ in the $1^{\text {st }}$ and 24.85 in the $2^{\text {nd }}$ season $)$ cluster width $\left(15.81 \mathrm{~cm}\right.$ in the $1^{\text {st }}$ and $16.50 \mathrm{~cm}$ in the $2^{\text {nd }}$ season), berry length $\left(1.76 \mathrm{~cm}\right.$ in the $1^{\text {st }}$ and $1.77 \mathrm{~cm}$ in the $2^{\text {nd }}$ season $)$ and berry diameter $(1.71 \mathrm{~cm}$ in the $1^{\text {st }}$ and $1.74 \mathrm{~cm}$ in the $2^{\text {nd }}$ season). On the other side, control gave the lowest cluster length, width, berry length and diameter in both seasons.

The obtained data from the interaction between date of spraying (D), $\mathrm{H}_{2} \mathrm{CN}_{2}$ and GE indicated that, $5 \% \mathrm{GE}$ with $\mathrm{D}_{2}$ produced the highest cluster length, width, berry length and diameter in both seasons. While control with the three spraying date recorded the lowest cluster length, width, berry length and diameter in both seasons.

\section{Total Soluble Solid, Total Sugar and Total Acidity \%}

Concerning the results in table (10), total soluble solid, total sugar and total acidity were affected significantly by the three dates of spraying treatments in both seasons. Whoever, $\mathrm{D}_{2}$ produced the highest total soluble solid $\left(20.42 \%\right.$ in the $1^{\text {st }}$ and 21.33 in the $2^{\text {nd }}$ season), total sugars $(18.47 \%$ in the $1^{\text {st }}$ and 19.01 in the $2^{\text {nd }}$ season $)$ and the lowest total acidity $(0.53 \%$ in the $1^{\text {st }}$ and $0.52 \%$ in the $2^{\text {nd }}$ season). While, $\mathrm{D}_{1}$ decreased total soluble solid, ( $16.82 \%$ in the $1^{\text {st }}$ and $17.58 \%$ in the $2^{\text {nd }}$ season), total sugars $(14.65 \%$ in the $1^{\text {st }}$ and $15.21 \%$ in the $2^{\text {nd }}$ season $)$ and increased total acidity $(0.58 \%$ in both seasons).

In addition total soluble solid, total sugars and total acidity were significantly affected by all spraying treatments in both seasons. However, spraying 5\% GE increased total soluble solid, total sugar and decreased total acidity in both seasons. On the other side, control was significantly decreased in total soluble solid, total sugar and increased total acidity in both seasons.

The obtained data from the interaction between spraying dates (D), $\mathrm{H}_{2} \mathrm{CN}_{2}$ and $\mathrm{GE}$ resulted that, $5 \% \mathrm{GE}$ with $\left(\mathrm{D}_{2}\right)$ increased total soluble solid, total sugars and decreased total acidity in both seasons. While control with three date spraying gave the lowest total soluble solid, total sugars and the highest total acidity in both seasons. 
Table (9). Effect of spray in three times (D) with hydrogen cyanamide $\left(\mathrm{H}_{2} \mathrm{CN}_{2}\right)$ and garlic extract (GE) on cluster length, width, berry length and diameter in flame seedless grapevine at 2016 and 2017.

\begin{tabular}{|c|c|c|c|c|c|c|c|c|c|}
\hline \multirow{2}{*}{\multicolumn{2}{|c|}{ Treatments }} & \multicolumn{2}{|c|}{$\begin{array}{l}\text { Cluster length } \\
\text { (cm) }\end{array}$} & \multicolumn{2}{|c|}{$\begin{array}{l}\text { Cluster width } \\
\text { (cm) }\end{array}$} & \multicolumn{2}{|c|}{$\begin{array}{l}\text { Berry length } \\
\text { (cm) }\end{array}$} & \multicolumn{2}{|c|}{$\begin{array}{l}\text { Berry diameter } \\
(\mathrm{cm})\end{array}$} \\
\hline & & $\begin{array}{c}\text { Season } \\
2016 \\
\end{array}$ & $\begin{array}{c}\text { Season } \\
2017\end{array}$ & $\begin{array}{c}\text { Season } \\
2016 \\
\end{array}$ & $\begin{array}{c}\text { Season } \\
2017\end{array}$ & $\begin{array}{c}\text { Season } \\
2016 \\
\end{array}$ & $\begin{array}{c}\text { Season } \\
2017 \\
\end{array}$ & $\begin{array}{c}\text { Season } \\
2016\end{array}$ & $\begin{array}{c}\text { Season } \\
2017 \\
\end{array}$ \\
\hline \multicolumn{10}{|c|}{ Effect of date spraying (D) } \\
\hline \multicolumn{2}{|l|}{$D_{1}$} & $20.24 c$ & $21.74 \mathrm{c}$ & $12.49 \mathrm{c}$ & $13.32 \mathrm{c}$ & $1.49 \mathrm{c}$ & $1.50 \mathrm{c}$ & $1.40 \mathrm{c}$ & $1.43 \mathrm{c}$ \\
\hline \multicolumn{2}{|l|}{$\mathbf{D}_{2}$} & $23.03 \mathrm{a}$ & $24.64 \mathrm{a}$ & $15.76 \mathrm{a}$ & $16.58 \mathrm{a}$ & $1.77 \mathrm{a}$ & $1.78 \mathrm{a}$ & $1.72 \mathrm{a}$ & $1.75 \mathrm{a}$ \\
\hline \multicolumn{2}{|c|}{$\mathbf{D}_{3}$} & $21.49 \mathrm{~b}$ & $23.20 \mathrm{~b}$ & $14.31 \mathrm{~b}$ & $14.82 \mathrm{~b}$ & $1.62 \mathrm{~b}$ & $1.63 \mathrm{~b}$ & $1.56 \mathrm{~b}$ & $1.61 \mathrm{~b}$ \\
\hline \multicolumn{10}{|c|}{ Effect of spraying hydrogen cyanamide $\left(\mathrm{H}_{2} \mathrm{CN}_{2}\right)$ and garlic extract (GE) } \\
\hline & $18.21 \mathrm{~d}$ & $19.88 \mathrm{~d}$ & $11.40 \mathrm{~d}$ & $12.17 \mathrm{~d}$ & $1.39 \mathrm{e}$ & $1.39 \mathrm{e}$ & $1.31 \mathrm{e}$ & $1.34 \mathrm{e}$ \\
\hline \multicolumn{2}{|c|}{$\mathrm{H}_{2} \mathrm{CN}_{2}(3 \%)$} & $21.84 \mathrm{c}$ & $23.37 \mathrm{c}$ & $14.17 \mathrm{c}$ & $14.84 \mathrm{c}$ & $1.62 \mathrm{~d}$ & $1.63 \mathrm{~d}$ & $1.55 \mathrm{~d}$ & $1.58 \mathrm{~d}$ \\
\hline \multicolumn{2}{|c|}{$\mathrm{H}_{2} \mathrm{CN}_{2}(5 \%)$} & $22.18 \mathrm{c}$ & $23.51 \mathrm{c}$ & $14.56 \mathrm{c}$ & 15.2 & $1.66 \mathrm{c}$ & $1.67 \mathrm{c}$ & $1.60 \mathrm{c}$ & $1.62 \mathrm{c}$ \\
\hline \multicolumn{2}{|c|}{ GE (3\%) } & $22.59 b$ & $24.35 b$ & $15.00 \mathrm{~b}$ & $15.82 b$ & $1.72 b$ & $1.72 b$ & $1.64 \mathrm{~b}$ & $1.68 \mathrm{~b}$ \\
\hline \multicolumn{2}{|c|}{ GE $(5 \%)$} & $23.12 \mathrm{a}$ & $24.85 \mathrm{a}$ & $15.81 \mathrm{a}$ & $16.50 \mathrm{a}$ & $1.76 \mathrm{a}$ & $1.77 \mathrm{a}$ & $1.71 \mathrm{a}$ & $1.74 \mathrm{a}$ \\
\hline \multicolumn{10}{|c|}{ The interaction between spraying dates (D) and hydrogen cyanamide $\left(\mathrm{H}_{2} \mathrm{CN}_{2}\right)$ and garlic extract $(\mathrm{GE})$} \\
\hline \multirow{2}{*}{ Date } & \multirow{2}{*}{ Treatments } & \multicolumn{2}{|c|}{$\begin{array}{c}\text { Cluster length } \\
\text { (cm) }\end{array}$} & \multicolumn{2}{|c|}{$\begin{array}{l}\text { Cluster width } \\
\text { (cm) }\end{array}$} & \multicolumn{2}{|c|}{$\begin{array}{l}\text { Berry length } \\
\text { (cm) }\end{array}$} & \multicolumn{2}{|c|}{$\begin{array}{c}\text { Berry diameter } \\
\text { (cm) }\end{array}$} \\
\hline & & $\begin{array}{c}\text { Season } \\
2016\end{array}$ & $\begin{array}{c}\text { Season } \\
2017\end{array}$ & $\begin{array}{c}\text { Season } \\
2016\end{array}$ & $\begin{array}{c}\text { Season } \\
2017\end{array}$ & $\begin{array}{c}\text { Season } \\
2016 \\
\end{array}$ & $\begin{array}{c}\text { Season } \\
2017 \\
\end{array}$ & $\begin{array}{c}\text { Season } \\
2016\end{array}$ & $\begin{array}{c}\text { Season } \\
2017 \\
\end{array}$ \\
\hline \multirow[t]{5}{*}{$D_{1}$} & Control & $18.21 \mathrm{j}$ & $19.96 \mathrm{j}$ & $11.71 \mathrm{jkl}$ & $12.50 \mathrm{ij}$ & $1.40 \mathrm{~m}$ & $1.39 \mathrm{~m}$ & $1.31 \mathrm{~m}$ & $1.35 \mathrm{mn}$ \\
\hline & $\mathrm{H}_{2} \mathrm{CN}_{2}(3 \%)$ & $20.22 \mathrm{i}$ & $21.43 \mathrm{i}$ & $12.00 \mathrm{jk}$ & $12.83 \mathrm{hi}$ & 1.471 & 1.481 & 1.341 & 1.371 \\
\hline & $\mathrm{H}_{2} \mathrm{CN}_{2}(5 \%)$ & $20.55 \mathrm{hi}$ & $21.87 \mathrm{hi}$ & $12.28 \mathrm{ij}$ & $13.16 \mathrm{~h}$ & $1.50 \mathrm{k}$ & $1.51 \mathrm{k}$ & $1.37 \mathrm{k}$ & $1.41 \mathrm{k}$ \\
\hline & GE (3\%) & $21.00 \mathrm{gh}$ & $22.53 \mathrm{gh}$ & 13.01hi & $13.85 \mathrm{~g}$ & $1.54 \mathrm{j}$ & $1.54 \mathrm{j}$ & $1.45 \mathrm{j}$ & $1.49 \mathrm{j}$ \\
\hline & GE $(5 \%)$ & $21.23 \mathrm{fg}$ & $22.91 \mathrm{fg}$ & $13.46 \mathrm{gh}$ & $14.28 \mathrm{~g}$ & $1.57 \mathrm{i}$ & $1.58 \mathrm{i}$ & $1.53 \mathrm{i}$ & $1.56 \mathrm{i}$ \\
\hline \multirow[t]{5}{*}{$\mathbf{D}_{1}$} & Control & $18.31 \mathrm{j}$ & $19.88 \mathrm{j}$ & $11.25 \mathrm{kl}$ & $12.25 \mathrm{jk}$ & $1.39 \mathrm{~m}$ & $1.39 \mathrm{~m}$ & $1.32 \mathrm{~m}$ & $1.35 \mathrm{~m}$ \\
\hline & $\mathrm{H}_{2} \mathrm{CN}_{2}(3 \%)$ & $23.65 \mathrm{bc}$ & $25.24 b c$ & $16.05 \mathrm{c}$ & $16.87 \mathrm{~cd}$ & $1.80 \mathrm{~d}$ & $1.80 \mathrm{~d}$ & $1.74 d$ & $1.76 \mathrm{~d}$ \\
\hline & $\mathrm{H}_{2} \mathrm{CN}_{2}(5 \%)$ & $24.00 \mathrm{bc}$ & $25.45 b c$ & $16.54 b c$ & $17.28 \mathrm{c}$ & $1.84 \mathrm{c}$ & $1.85 \mathrm{c}$ & $1.81 \mathrm{c}$ & $1.84 \mathrm{c}$ \\
\hline & GE (3\%) & $24.22 \mathrm{ab}$ & 25.83ab & $17.00 \mathrm{~b}$ & $17.80 \mathrm{~b}$ & $1.90 \mathrm{~b}$ & $1.90 \mathrm{~b}$ & $1.84 \mathrm{~b}$ & $1.88 \mathrm{~b}$ \\
\hline & GE $(5 \%)$ & $25.00 \mathrm{a}$ & $26.81 \mathrm{a}$ & $18.00 \mathrm{a}$ & $18.72 \mathrm{a}$ & $1.95 \mathrm{a}$ & $1.96 \mathrm{a}$ & $1.91 \mathrm{a}$ & $1.94 \mathrm{a}$ \\
\hline \multirow[t]{5}{*}{$\mathbf{D}_{3}$} & Control & $18.11 \mathrm{j}$ & $19.80 \mathrm{j}$ & 11.241 & $11.76 \mathrm{k}$ & $1.39 \mathrm{~m}$ & $1.39 \mathrm{~m}$ & $1.31 \mathrm{~m}$ & $1.34 \mathrm{n}$ \\
\hline & $\mathrm{H}_{2} \mathrm{CN}_{2}(3 \%)$ & $21.65 \mathrm{fg}$ & $23.44 \mathrm{fg}$ & $14.47 \mathrm{fg}$ & $14.83 \mathrm{f}$ & $1.60 \mathrm{~h}$ & $1.60 \mathrm{~h}$ & $1.58 \mathrm{~h}$ & $1.62 \mathrm{~h}$ \\
\hline & $\mathrm{H}_{2} \mathrm{CN}_{2}(5 \%)$ & $22.00 \mathrm{ef}$ & $23.23 \mathrm{ef}$ & $14.88 \mathrm{ef}$ & $15.23 \mathrm{f}$ & $1.64 \mathrm{~g}$ & $1.65 \mathrm{~g}$ & $1.61 \mathrm{~g}$ & $1.63 \mathrm{~g}$ \\
\hline & GE (3\%) & $22.55 \mathrm{de}$ & $24.71 \mathrm{de}$ & $15.00 \mathrm{de}$ & $15.81 \mathrm{e}$ & $1.72 \mathrm{f}$ & $1.72 \mathrm{f}$ & $1.64 \mathrm{f}$ & $1.67 \mathrm{f}$ \\
\hline & GE (5\%) & $23.14 \mathrm{~cd}$ & $24.85 \mathrm{~cd}$ & $15.98 \mathrm{~cd}$ & $16.50 \mathrm{~d}$ & $1.76 \mathrm{e}$ & $1.77 \mathrm{e}$ & $1.70 \mathrm{e}$ & $1.74 \mathrm{e}$ \\
\hline
\end{tabular}

Means having the same letter(s) in each column of first factor, second factor or interaction are not significantly different at $5 \%$ level. $\mathrm{D}_{1}=$ the first of December, $\mathrm{D}_{2}=$ mid of December and $\mathrm{D}_{3}=$ the end of December. *While, control= sprayed with tap water, $\mathrm{H}_{2} \mathrm{CN}_{2}(3 \%)=$ hydrogen cyanamide $(3 \%), \mathrm{H}_{2} \mathrm{CN}_{2}(5 \%)=$ hydrogen cyanamide $(5 \%)$, GE $(3 \%)=$ garlic extract $(3 \%)$ and GE $(5 \%)=$ garlic extract $(5 \%)$.

Egyptian J. Desert Res., 68, No. 2, 199-222 (2018) 
Table (10). Effect of spray in three times (D) with hydrogen cyanamide $\left(\mathrm{H}_{2} \mathrm{CN}_{2}\right)$ and garlic extract (GE) on total soluble solid, total sugar and total acidity $\%$ in flame seedless grapevine at 2016 and 2017.

\begin{tabular}{|c|c|c|c|c|c|c|}
\hline \multirow{2}{*}{ Treatments } & \multicolumn{2}{|c|}{ TSS (\%) } & \multicolumn{2}{|c|}{ Total sugar (\%) } & \multicolumn{2}{|c|}{ Total acidity (\%) } \\
\hline & $\begin{array}{c}\text { Season } \\
2016\end{array}$ & $\begin{array}{c}\text { Season } \\
2017 \\
\end{array}$ & $\begin{array}{c}\text { Season } \\
2016\end{array}$ & $\begin{array}{c}\text { Season } \\
2017 \\
\end{array}$ & $\begin{array}{c}\text { Season } \\
2016 \\
\end{array}$ & $\begin{array}{c}\text { Season } \\
2017 \\
\end{array}$ \\
\hline \multicolumn{7}{|c|}{ Effect of date spraying (D) } \\
\hline $\mathbf{D}_{1}$ & $16.82 \mathrm{c}$ & $17.58 \mathrm{c}$ & $14.65 \mathrm{c}$ & $15.21 \mathrm{c}$ & $0.58 \mathrm{a}$ & $0.58 \mathrm{a}$ \\
\hline $\mathbf{D}_{2}$ & $20.42 \mathrm{a}$ & $21.33 \mathrm{a}$ & $18.47 \mathrm{a}$ & $19.01 \mathrm{a}$ & $0.53 \mathrm{c}$ & $0.52 \mathrm{c}$ \\
\hline $\mathbf{D}_{3}$ & $18.04 \mathrm{~b}$ & $18.89 \mathrm{~b}$ & $16.04 \mathrm{~b}$ & $16.53 b$ & $0.56 \mathrm{~b}$ & $0.55 \mathrm{~b}$ \\
\hline \multicolumn{7}{|c|}{ Effect of spraying hydrogen cyanamide $\left(\mathrm{H}_{2} \mathrm{CN}_{2}\right)$ and garlic extract (GE) } \\
\hline Control & $15.24 \mathrm{~d}$ & $16.06 \mathrm{~d}$ & $13.20 \mathrm{e}$ & $13.71 \mathrm{e}$ & $0.59 \mathrm{a}$ & $0.59 \mathrm{a}$ \\
\hline $\mathrm{H}_{2} \mathrm{CN}_{2}(3 \%)$ & $18.32 \mathrm{c}$ & $19.14 c$ & $16.28 \mathrm{~d}$ & $16.84 d$ & $0.56 \mathrm{~b}$ & $0.55 \mathrm{~b}$ \\
\hline $\mathrm{H}_{2} \mathrm{CN}_{2}(5 \%)$ & $18.94 b$ & $19.81 \mathrm{~b}$ & $16.84 \mathrm{c}$ & $17.35 c$ & $0.55 \mathrm{c}$ & $0.54 \mathrm{c}$ \\
\hline GE $(3 \%)$ & $19.45 b$ & $20.26 \mathrm{~b}$ & $17.40 \mathrm{~b}$ & $17.93 b$ & $0.54 \mathrm{~d}$ & $0.54 d$ \\
\hline GE (5\%) & $20.18 \mathrm{a}$ & $21.08 \mathrm{a}$ & $18.21 \mathrm{a}$ & $18.76 \mathrm{a}$ & $0.53 \mathrm{e}$ & $0.53 \mathrm{~d}$ \\
\hline
\end{tabular}

The interaction between spraying dates (D) and hydrogen cyanamide $\left(\mathrm{H}_{2} \mathrm{CN}_{2}\right)$ and garlic extract (GE)

\begin{tabular}{|c|c|c|c|c|c|c|c|}
\hline \multirow[b]{2}{*}{ Date } & \multirow[b]{2}{*}{ Treatment } & \multicolumn{2}{|c|}{ TSS (\%) } & \multicolumn{2}{|c|}{ Total sugar (\%) } & \multicolumn{2}{|c|}{ Total acidity (\%) } \\
\hline & & $\begin{array}{c}\text { Season } \\
2016\end{array}$ & $\begin{array}{c}\text { Season } \\
2017\end{array}$ & $\begin{array}{c}\text { Season } \\
2016\end{array}$ & $\begin{array}{c}\text { Season } \\
2017\end{array}$ & $\begin{array}{c}\text { Season } \\
2016\end{array}$ & $\begin{array}{c}\text { Season } \\
2017\end{array}$ \\
\hline \multirow[t]{5}{*}{$\mathbf{D}_{1}$} & Cont. & $15.53 \mathrm{i}$ & $16.15 i$ & $13.31 \mathrm{j}$ & $13.86 \mathrm{j}$ & $0.59 \mathrm{a}$ & $0.60 \mathrm{a}$ \\
\hline & $\mathrm{H}_{2} \mathrm{CN}_{2}(3 \%)$ & $16.37 \mathrm{~h}$ & $17.01 \mathrm{~h}$ & $14.22 \mathrm{i}$ & $14.81 \mathrm{i}$ & $0.58 b$ & $0.58 \mathrm{bc}$ \\
\hline & $\mathrm{H}_{2} \mathrm{CN}_{2}(5 \%)$ & $17.28 \mathrm{~g}$ & $18.14 \mathrm{~g}$ & 15.00hi & $15.45 \mathrm{hi}$ & $0.58 b c$ & $0.57 \mathrm{~cd}$ \\
\hline & GE (3\%) & $17.27 \mathrm{~g}$ & $18.11 \mathrm{~g}$ & $15.22 \mathrm{gh}$ & $15.76 \mathrm{gh}$ & $0.57 \mathrm{~cd}$ & $0.57 \mathrm{~cd}$ \\
\hline & GE (5\%) & $17.65 \mathrm{fg}$ & $18.52 \mathrm{fg}$ & $15.54 \mathrm{fgh}$ & $16.20 \mathrm{fgh}$ & $0.57 \mathrm{de}$ & $0.56 \mathrm{de}$ \\
\hline \multirow[t]{5}{*}{$\mathbf{D}_{2}$} & Cont. & $15.00 \mathrm{i}$ & $15.85 \mathrm{i}$ & $13.00 \mathrm{j}$ & $13.47 \mathrm{j}$ & $0.59 a$ & $0.60 \mathrm{a}$ \\
\hline & $\mathrm{H}_{2} \mathrm{CN}_{2}(3 \%)$ & $20.61 \mathrm{c}$ & $21.54 \mathrm{c}$ & $18.61 \mathrm{c}$ & $19.28 \mathrm{c}$ & $0.52 \mathrm{~h}$ & $0.52 \mathrm{hi}$ \\
\hline & $\mathrm{H}_{2} \mathrm{CN}_{2}(5 \%)$ & $21.23 b c$ & $22.19 b c$ & $19.30 \mathrm{bc}$ & $19.88 \mathrm{bc}$ & $0.51 \mathrm{i}$ & $0.51 \mathrm{ij}$ \\
\hline & GE (3\%) & $22.00 \mathrm{~b}$ & $22.88 \mathrm{~b}$ & $20.00 \mathrm{~b}$ & $20.62 \mathrm{~b}$ & $0.50 \mathrm{j}$ & $0.50 \mathrm{jk}$ \\
\hline & GE (5\%) & $23.30 \mathrm{a}$ & $24.22 \mathrm{a}$ & $21.45 \mathrm{a}$ & $21.82 \mathrm{a}$ & $0.50 \mathrm{j}$ & $0.50 \mathrm{k}$ \\
\hline \multirow[t]{5}{*}{$\mathbf{D}_{3}$} & Control & $15.19 \mathrm{i}$ & $16.20 \mathrm{i}$ & $13.31 \mathrm{j}$ & $13.81 \mathrm{j}$ & $0.600 \mathrm{a}$ & $0.59 \mathrm{ab}$ \\
\hline & $\mathrm{H}_{2} \mathrm{CN}_{2}(3 \%)$ & $18.00 \mathrm{fg}$ & $18.87 \mathrm{fg}$ & $16.01 \mathrm{fg}$ & $16.44 \mathrm{fg}$ & $0.56 \mathrm{e}$ & $0.56 \mathrm{de}$ \\
\hline & $\mathrm{H}_{2} \mathrm{CN}_{2}(5 \%)$ & $18.31 \mathrm{ef}$ & 19.10ef & $16.22 \mathrm{ef}$ & $16.73 \mathrm{ef}$ & $0.55 \mathrm{f}$ & $0.55 \mathrm{ef}$ \\
\hline & GE (3\%) & 19.10de & $19.81 \mathrm{de}$ & $17.00 \mathrm{de}$ & $17.41 \mathrm{de}$ & $0.54 \mathrm{~g}$ & $0.54 \mathrm{fg}$ \\
\hline & GE (5\%) & $19.61 \mathrm{~d}$ & $20.50 \mathrm{~d}$ & $17.66 \mathrm{~d}$ & $18.27 \mathrm{~d}$ & $0.54 \mathrm{~g}$ & $0.53 \mathrm{gh}$ \\
\hline
\end{tabular}

Means having the same letter(s) in each column of first factor, second factor or interaction are not significantly different at $5 \%$ level. $\mathrm{D}_{1}=$ the first of December, $\mathrm{D}_{2}=$ mid of December and $\mathrm{D}_{3}=$ the end of December. *While, control= sprayed with tap water, $\mathrm{H}_{2} \mathrm{CN}_{2}(3 \%)=$ hydrogen cyanamide $(3 \%), \mathrm{H}_{2} \mathrm{CN}_{2}(5 \%)=$ hydrogen cyanamide $(5 \%), \mathrm{GE}(3 \%)=$ garlic extract $(3 \%)$ and $\mathrm{GE}(5 \%)=$ garlic extract $(5 \%)$. 
These results in tables $(8,9$ and 10$)$ may be due to that GE enhanced cell division and elongation as well as the tolerance of plants to different stresses. Garlic extract enhanced growth and vine nutritional status that shifted the balance of competition between growth and reproductive organs that was in favor of the latter. In addition, the positive action of these extracts on stimulating the biosynthesis of sugars and plant pigments is surely reflected on advancing maturity and promoting fruit quality (Kubota et al., 2000; Corrales-Maldonado et al., 2010; Ali et al., 2012; Gadel-Kareem and AbdelRahman, 2013; Uwakiem, 2014; Gouda, 2016 and Rizkalla, 2016).

The obtained results are in agreement with those reported by ElDesouky et al. (1998) and Wanas et al. (1998) on squash plant, Serag El-Deen (2002) on grapevine, Botelho et al. (2007) on apple, Chowdhury et al. (2007) on mango, Ahmed et al. (2009) on peach, Abd El-Razek et al. (2011) on 'Canino' apricot, Abd El-Razek et al. (2013) on 'Le Conte' pear, El-Sharony et al. (2015) on mango cv. Fagri Kalan, Sheren and Eman (2015) on pear and El-Salhy et al. (2017) on Flame Seedless grapevines. All previous researchers generally found that the natural extract of garlic cloves improved both of fruit yield and quality.

\section{CONCLUSION}

Regarding mentioned results it can be concluded that spraying Flame Seedless grapevine with GE at $5 \%$ on mid-December is the best treatment for harvesting earlier than spraying in the usual time. In addition, this treatment could be one of the valuable technologies that assist in improving plant growth, fruit quality and vine productivity. Moreover, substitution of garlic as a naturally friendly environmental material instead of $\mathrm{H}_{2} \mathrm{CN}_{2}$, which could be recommended to break vine bud dormancy without any harmful dangers on human health.

\section{REFERENCES}

A.O.A.C (1985). In "Official Methods of Analysis of the Association of Official Analytical Chemists". Published by the A.O.A.C. $16^{\text {th }}$ Ed. Washington, D.C.

A.O.A.C. (1990). In "Official Methods of Analysis", $15^{\text {th }}$ Ed. Association of Official Analytical Chemistry, Arlington, Virginia, USA.

Abd El-Razek, E., M.M.M. Abd El -Migeed and N. Abdel-Hamid (2011). Effect of spraying garlic extract and olive oil on flowering behavior, yield and fruit quality of 'Canino' apricot trees. American-Eurasian J. Agric. Environ. Sci., 11 (6): 776-781.

Egyptian J. Desert Res., 68, No. 2, 199-222 (2018) 
Abd El-Razek, E., M.M.M. Abd El-Migeed and N. Abdel-Hamid (2013). Response of 'Le Conte' pear trees to garlic extract and GA as bud break dormancy agents. Middle-East Journal of Scientific Research, 14 (11): 1407-1413.

Ahmed, M.A.M., A.A. Eman and M.M.M. Abd El-Migeed (2009). Effect of garlic extract and mineral oil spray on flowering, harvesting time, yield and fruit quality of peach trees c.v. 'Florida prince'. Eastern Russian J. Plant Sci. Biotechnol., 3: 53-57.

Ali, M.A., S.M. Shawky and G.S. Shaker (2012). Comparative efficacy of some bio -agents plant oil and plant aqueous extracts in controlling Meloidogyne incognita on growth and yield of grapevines. Annals of Agricultural Sciences, 57 (1): 7-18.

Arispuro, I.V., C.C. Maldonado and M.A.M. Tellez (2008). Compounds derived from garlic and bud. inclusion agents in organic farming of table grape. Chilean J. Agric. Res., 68: 97-101.

Ben Mohamed, H., A.M. Vadel, J.M.C. Geuns and H. Khemira (2010). Biochemical changes in dormant grapevine shoot tissues in response to chilling: Possible role in dormancy release. Scientia Horticulturae, 124: 440-447.

Bessies, R. (1990). Different modes of quantitative expression of fertility in grapevine (Different methods of expressing vines productivity quantitatively). Rendering Report Weekly Acad. Sessions. Agric. Fr., 46: 828-832.

Botelho, R.V. and M.M. Müller (2007a). Evaluation of garlic extract on bud dormancy release of "Royal Gala" apple trees. Australian Journal of Experimental Agriculture, 47: 738-741.

Botelho, R.V. and M.M. Müller (2007b). Garlic extract as alternative on bud dormant break of apple trees cv. Fuji Kiku. Revista Brasileira de Fruticultura, 29: 37-41.

Botelho, R.V., A.P. Pavanello, J.P. Pires and M.M.L. Muller (2007). Effects of chilling and garlic extract on bud dormancy release in Carbernet Sauvignon grapevine cuttings. Am. J. Enol. Vitic., 58: 402-404.

Botelho, R.V., E.J. Pires, M.F. Mou Ra, M.M. Terra and M.A. Tecchio (2010). Garlic extract improves bud break of the "Niagara" grapevines on sub-tropical regions. Ciencia Rural, Santa Maria, 40: 2282-2287.

Chowdhury, M.N.A., M.A. Rahim, K.M. Khalequzzaman, M.R. Humauan and M.M. Alam (2007). Effect of plant extracts and time of application on incidence of anthracnose, yield and quality of mango. Int. J. Sustain. Crop Production, 2 (5): 59-68.

Corrales-Maldonado, C., M.A. Martinez-Tellez, A.A. Gardea, A. OrozcoAvitia and V. Arispuro (2010). Organic alternative for breaking

Egyptian J. Desert Res., 68, No. 2, 199-222 (2018) 
dormancy in table grapes grown in hot regions. American Journal of Agricultural and Biological Sciences, 5 (2): 143-147.

Dimitri, C. and L. Oberholtzer (2006). EU and US organic markets face strong demand under different policies. Amber Waves Economic Research Service USDA, 4: 12-19.

Dookoozlian, N. and E. Wiliams (1995). Chilling exposure and hydrogen cyanamide interact in breaking dormancy of grape buds. Hort. Sci., 30: $1244-1247$.

Duncan, D.B (1955). Multiple range and multiple F tests. Biometrics, 11: $1-$ 24.

El-Desouky, S.A., A.L.A. Wanas and Z.M.A. Khedr (1998). Utilization of some natural plant extracts (of garlic and yeast) as seed-soaked materials to squash (Cucurbita pepo L.). 1- Effect on growth, sex expression and fruit yield and quality. Annals Agric. Sci. Moshtohor, 36 (2): 839-854.

El-Salhy, A.M., R.A. Ibrahim, Mgawer and G.N. Abd El-Hafiz (2017). Effect of some plant extracts spraying on growth and fruiting of flame seedless grapevines. Assiut J. Agric. Sci., 48 (3): 188-197.

El-Sharony, T.F., S.F. El-Gioushy and O.A. Amin (2015). Effect of foliar application with algae and plant extracts on growth, yield and fruit quality of fruitful mango trees cv. Fagri Kalan. J. Hort., 2: 162.

Fraga, H., A.C. Malheiro, J. Moutinho-Pereira and J.A. Santos (2014). Climate factors driving wine production in the Portuguese Minho region. Agricultural and Forest Meteorology,185: 26-36.

Fraga, H., J.A. Santos, A.C. Malheiro, A.A. Oliveira, J. Moutinho-Pereira and G.V. Jones (2015). Climatic suitability of Portuguese grapevine varieties and climate change adaptation. Int. J. Clim.: doi:10.1002/joc. 4325 .

Gadel-Kareem, M.R. and M.A. Abdel-Rahman (2013). Response of Ruby Seedless grapevines to foliar application of seaweed extract, salicylic acid and roselle extract. Hortscience J. Suez Canal Univ., 1: 299303.

Gladstones, J. (2016). In "Viticulture and Environment". Revised Edition. Trivinum Press, Tanunda, South Australia.

Gouda, F.Z.M. (2016). Effect of $\mathrm{GA}_{3}$ and lemongrass oil spraying on fruiting of Ruby Seedless grapevines. J. Agric. Sci., 47 (6-1): 173-180.

Harris, J.C., S. Cottrell and D. Lloyd (2001). Antimicrobial properties of Allium sativum (garlic). Applied Microbiology and Biotechnology, 57: 282-286.

Hawerroth, F.J., F.G. Herter, J.L. Petri, A.C. Marafon and J.L. Leonetti (2013). Evaluation of winter temperatures on apple bud break using grafted twigs. Revista Brasileira de Fruticultura, 35 (3): 713-721.

Egyptian J. Desert Res., 68, No. 2, 199-222 (2018) 
Hosoki, T., M. Hamada and K. Inaba (1984). Forcing of tree peon for December shipping by pre-chilling and chemical treatments. J. Japan Soc. Hort. Sci., 53: 187-193.

IPCC (2014a). Climate Change (2014). Mitigation of Climate Change. Contribution of Working Group III to the Fifth Assessment Report of the Intergovernmental Panelon Climate Change. Cambridge University Press, Cambridge, New York.

IPCC (2014b). "Climate Change (2014). Synthesis Report, in Contribution of Working Groups I, II and III to the Fifth Assessment Report of the Intergovernmental Panel on Climate Change, eds Core Writing Team, Pachauri, R.K. and L.A. Meyer (Geneva: IPCC), 151 pp.

Jullyanna, N.C., L.S. Pereira, P.A. de Carvalho and A.D. Neto (2016). Application of natural garlic extract to overcome bud dormancy of grapevines 'BRS Rúbea' and 'BRS Cora'. Australian Journal Crop Science, 10 (2): 216-219.

Kim, S. and S. Kim (2000). Effects of allium, merit blue and soluble PK formulate on bud break in differentially Chilled Compbell Early grapevines. J. Korean Soc. Hort. Sci., 41 (3): 265-268.

Kim, S.K. and S.H. Kim (1999). Effect of garlic and onion based formulae and Merit Blue on bud break and maturity of "Daebong" grapes (Vitis labruscana B.) in forcing culture. Korean J. Hortic. Sci. Technol., 17 (2): 123-126.

Kubota, N., Y. Yamane, K. Toriu, K. Kawasu and T. Higuchi (1999). Identification of active substances in garlic responsible for breaking bud dormancy in grapevines. J. Jap. Soc. Hortic. Sci., 68: 1111-1117.

Kubota, N., M.A. Matthew, T. Takahugl and W.M. Kliewer (2000). Effect of garlic preparations, calcium and hydrogen cyanamides on bud break of grapevines grown in greenhouse. American J. Enology Viticulture, (51): 409-414.

Kubota, N. and M. Miyamuki (1992). Breaking bud dormancy in grapevines with garlic paste. J. Am. Soc. Hortic. Sci., 117: 898-901.

Lavee, S., Y. Shulman and G. Nir. (1984). The Effect of Cyanamide on Bud Break of Grapevines (Vitis vinifera L.), p. 17-29. In: Weaver, R.J. (ed.). Proceedings of Symposium on Bud Dormancy in Grapevine: Potential and Practical Uses of Hydrogen Cyanamide on Grapevine. Univ. California, Davis.

Leonel, S., M.A. Tecchio and G.M. De Angeli Gilli Cóser (2015). Dormancy breaking of the fig tree with hydrogen cyanamide and garlic extract. British Journal of Applied Science and Technology, 10 (1): 1-10.

Lin, C. and T.Y. Wang (1985). Enhancement of bud sprouting in grape single bud cutting by cyanamide. Am. J. Enol. Viticult., 36: 15-17. 
Mostafa, M.R. and M.A.S. El-Yazal (2013). Response of "Anna" apple dormant buds and carbohydrate metabolism during floral bud break to onion extract. Scientia Horticulturae, 144: 78-94.

Nir, G., I. Klein, S. Lavee, G. Spieler and U. Barak (1988). Improving grapevine budbreak and yields by evaporative cooling. J. Am. Soc. Hortic. Sci.,113: 512-517.

Oliveira, B., B. Lipski, E.D.B. Silva, L.A. Biasi and S.S. Coelho (2009). Extract of garlic in overcoming the dormancy of pear tree 'housui'. Scientia Agraria., 10 (4): 283-288.

Pandya, K., B. Solanki, K. Maniar, N. Gurav and S. Bhatt (2011). Natural herbal supplements - A study on the nutritional value and their phytochemical constituents. International Journal of Pharmaceutical Science and Research, 2: 1480-1494.

Pinto, M., V. Lira, H. Ugalde and F. Pérez (2007). Physiology of latency of grapevines: current hypotheses. Santiago: University of Chile, $16 \mathrm{p}$.

Rizkalla, M.K. (2016). Effect of spraying natural camphor and garlic oils on bud fertility, yield and fruit quality of Flame Seedless and White Banaty (Thompson Seedless) grape cultivars. Ph.D. Thesis, Fac. Agric., Assiut Univ., Egypt.

Serag El-Deen, M.M.M. (2002). Effect of some chemical and natural compounds on growth, fruiting and fruit storability of Thompson seedless grape. PhD. Thesis, Fac. Agric., Minufiya Univ., Egypt, 250 p.

Shaddad, A.M.G. (2010). Physiological studies on breaking bud dormancy of grapes (Vitis vinifera L.). Ph.D. Thesis, Fac. Agric., Ain Shams Univ., Egypt.

Sheren, A.A.H. and I.A. Eman (2015). Improving growth and productivity of "Pear" trees using some natural plants extracts under North Sinai conditions. IOSR Journal of Agriculture and Veterinary Science, 8 (1): $1-9$.

Uwakiem, M.K.H. (2014). The synergistic effect of spraying some plant extracts with some macro and micronutrients of Thompson Seedless grapevines. Inter. J. Plant Soil Sci., 3 (10): 1290- 1301.

Vasconcelos, R., A.E. Pozzobom, M. Paioli, Monteiro and M. Lopes (2007). Effects of chilling and garlic extract on bud dormancy release in cabernet sauvignon grapevine cuttings. Am. J. Enol. Viticult., 58 (3): 402-404.

Wanas, A.L.A., S.A. El-Desouky and Z.M.A. Kheder (1998). Utilization of some natural plant extracts (of garlic and yeast) as seed-soaked materials to squash (Cucurbita pepo L.). II-Effect on the histological features and the endogenous hormones. Annals Agric. Sci. Moshtohor, 36 (2): 855-878.

Egyptian J. Desert Res., 68, No. 2, 199-222 (2018) 
Wicks, A.S., J.O. Johnson, E. Bracho, F.L. Jensen, R.A. Neja, L.A. Lider and R.J. Weaver (1984). Induction of early and more uniform bud break in Vitis vinifera L. cvs. Perlette, Thompson Seedless, and Flame Seedless, p. 48-58. In: Weaver, R.J. (ed.). Proceedings of Symposium on Bud Dormancy in Grapevine: Potential and Practical Uses of Hydrogen Cyanamide on Grapevine. Univ. California, Davis.

Zelleke, A. and W. Kliewer (1989). The effects of hydrogen cyanamide on enhancing the time and amount of budbreak in young grape vineyards. Am. J. Enol. Viticult., 40: 47-51. 


\section{دراسة مقارنة بين مستخلص الثوم وسيناميد الهيلروجين على التزهير والعقد والانتاجية في العنب النب}

إيمان إبراهيم العماري وشيرين عادل عبد الحميد" الهير

قسم الإنتاج النباتي، مركز بحوث الصحر اءو، الدطرية، القاهرة، مصر

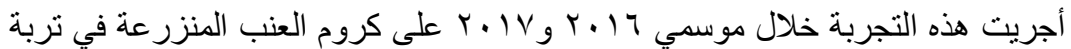

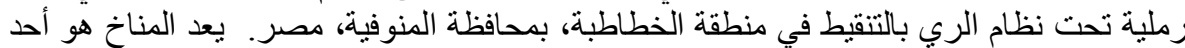

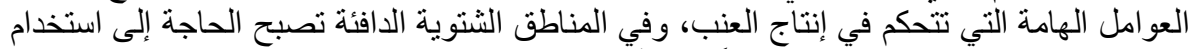

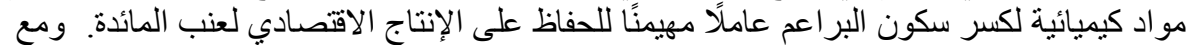

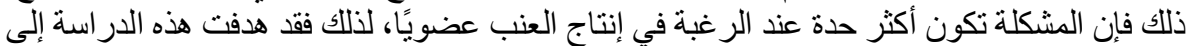

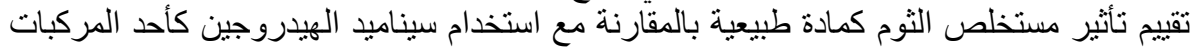

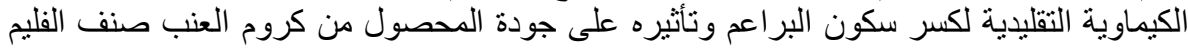

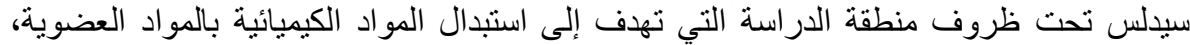

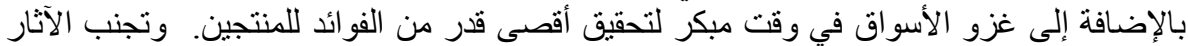

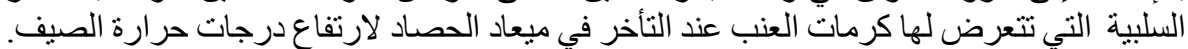

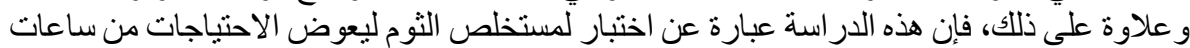

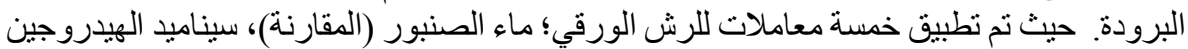

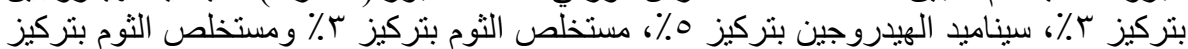

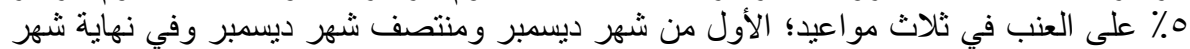

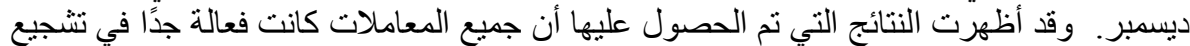

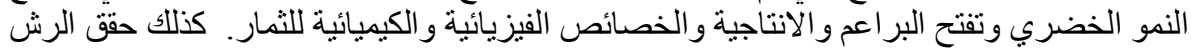

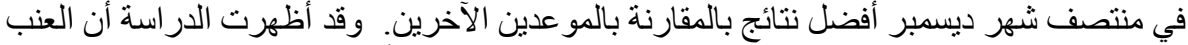

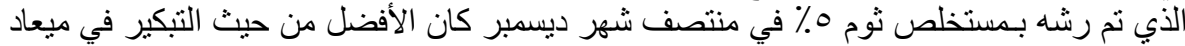

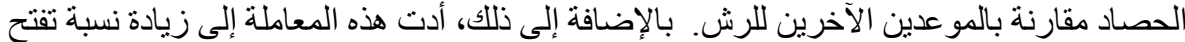

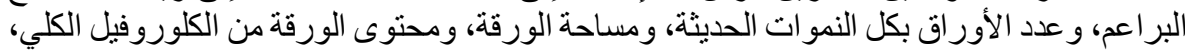

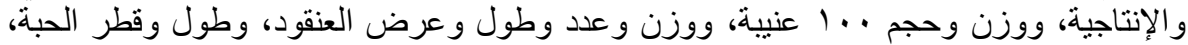
و المادة الصلبة الذائبة الكلية، و السكريات الكلية، وكذلك تم خفض عدول عدد الأيام للوصول وطل إلى التزهير الكامل وكذلك الحموضة الكلية الكلة.

Egyptian J. Desert Res., 68, No. 2, 199-222 (2018) 